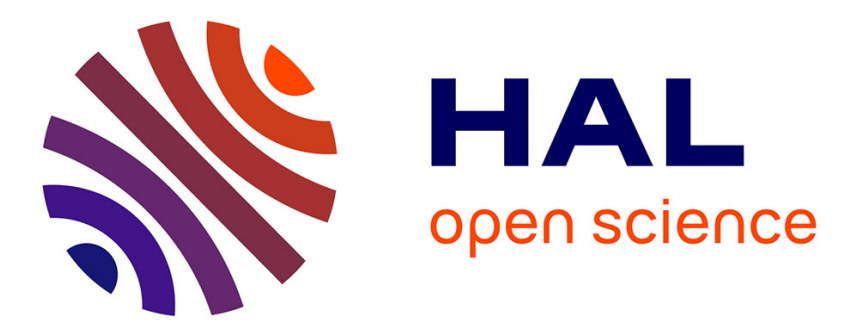

\title{
Fate of cadmium in the rhizosphere of Arabidopsis halleri grown in a contaminated dredged sediment
}

Stéphanie Huguet, M.-P. Isaure, Valérie Bert, Agnès Laboudigue, Olivier

Proux, Delphine Vantelon, Anne-Marie Flank, Géraldine Sarret

\section{To cite this version:}

Stéphanie Huguet, M.-P. Isaure, Valérie Bert, Agnès Laboudigue, Olivier Proux, et al.. Fate of cadmium in the rhizosphere of Arabidopsis halleri grown in a contaminated dredged sediment. Science of the Total Environment, 2015, 10.1016/j.scitotenv.2015.07.026 . hal-01256222

\section{HAL Id: hal-01256222}

https://hal-mines-paristech.archives-ouvertes.fr/hal-01256222

Submitted on 18 Jan 2016

HAL is a multi-disciplinary open access archive for the deposit and dissemination of scientific research documents, whether they are published or not. The documents may come from teaching and research institutions in France or abroad, or from public or private research centers.
L'archive ouverte pluridisciplinaire HAL, est destinée au dépôt et à la diffusion de documents scientifiques de niveau recherche, publiés ou non, émanant des établissements d'enseignement et de recherche français ou étrangers, des laboratoires publics ou privés. 
Fate of cadmium in the rhizosphere of Arabidopsis halleri grown in a contaminated dredged sediment.

Huguet Séphanie ${ }^{\mathrm{a}, \mathrm{b}, \mathrm{c}, \mathrm{d}}$, Isaure Marie-Pierre ${ }^{\mathrm{b}}$, Bert Valérie ${ }^{\mathrm{c}}$, Laboudigue Agnès ${ }^{\mathrm{d}, 1}$, Proux Olivier ${ }^{\mathrm{e}}$, Flank Anne-Marie ${ }^{\mathrm{f}, \mathrm{g}}$, Vantelon Delphine ${ }^{\mathrm{f}, \mathrm{g}}$ and Sarret Géraldine ${ }^{\mathrm{a}}$

${ }^{a}$ ISTerre, Université Grenoble Alpes, CNRS, F-38041 Grenoble, France.

b Laboratoire de Chimie Analytique Bio-Inorganique et Environnement (LCABIE), Institut des sciences analytiques et de physico-chimie pour l'environnement et les matériaux (IPREM UMR 5254), Université de Pau et des Pays de l'Adour and CNRS, Hélioparc, 2 Av. Pierre Angot, 64053 Pau Cedex 9, France.

${ }^{\mathbf{c}}$ INERIS, Parc technologique Alata, 60550 Verneuil-en-Halatte, France.

${ }^{\text {d }}$ EMDouai, MPE-GCE, 930 Boulevard Lahure, 59500 Douai, France.

e OSUG, UMS832 CNRS/UJF, 414 rue de la piscine, 38400 Saint -Martin d'Hères, France.

${ }^{\mathbf{f}}$ Beamline LUCIA, SLS, Swiss Light Source, CH-5232 Villigen, Switzerland.

${ }^{\text {g }}$ Synchrotron SOLEIL, F-91192 Gif Sur Yvette, France.

${ }^{1}$ Present address: Ecole des Mines de Paris, 60 boulevard St Michel 75272 Paris Cedex 06, France

\section{Corresponding authors:}

huguet.st@gmail.com

geraldine.sarret@ujf-grenoble.fr 
Keywords: Cadmium (Cd), sediment, Arabidopsis halleri, speciation, EXAFS, $\mu$ XANES, $\mu$ XRF, SEM-EDS, phytoavailability, DGT, leachates.

\begin{abstract}
In regions impacted by mining and smelting activities, dredged sediments are often contaminated with metals. Phytotechnologies could be used for their management, but more knowledge on the speciation of metals in the sediment and on their fate after colonization by plant roots is needed. This work was focused on a $\mathrm{Zn}$, Cd-contaminated contaminated dredged sediment from the Scarpe river (North of France). Zn, Cd hyperaccumulating plants Arabidopsis halleri from metallicolous and non metallicolous origin were grown on the sediment for five months in a pot experiment. The nature and extent of the modifications in $\mathrm{Cd}$ speciation with or without plant were determined by electron microscopy, micro X-ray fluorescence and bulk and micro X-ray absorption spectroscopy. In addition, changes in $\mathrm{Cd}$ exchangeable and bioavailable pools were evaluated, and $\mathrm{Cd}$ content in leachates was measured. Finally, Cd plant uptake and plant growth parameters were monitored. In the original sediment, $\mathrm{Cd}$ was present as a mixed $\mathrm{Zn}, \mathrm{Cd}$, Fe sulfide. After five months, although pots still contained reduced sulfur, Cd-bearing sulfides were totally oxidized in vegetated pots, whereas a minor fraction (8\%) was still present in non vegetated ones. Secondary species included $\mathrm{Cd}$ bound to O-containing groups of organic matter and $\mathrm{Cd}$ phosphates. $\mathrm{Cd}$ exchangeability and bioavailability were relatively low and did not increase during changes in $\mathrm{Cd}$ speciation, suggesting that $\mathrm{Cd}$ released by sulfide oxidation was readily taken up with strong interactions with organic matter and phosphate ligands. Thus, the composition of the sediment, the oxic conditions and the rhizospheric activity (regardless of the plant origin) created favourable conditions for Cd stabilization. However, it should be kept in mind that returning to anoxic conditions may change $\mathrm{Cd}$ speciation, so the species formed cannot be considered as stable on the long term.
\end{abstract}

\title{
1. Introduction
}

The North of France hosts one of the oldest and largest industrial areas in Europe, with a large concentration of non-ferrous metal processing activities. The Scarpe river is strongly 
impacted by these activities, and sediments are contaminated by many metals including $\mathrm{Zn}$ (about $7000 \mathrm{mg} \mathrm{kg}^{-1}$ ) (Isaure et al., 2002) and Cd (about $600 \mathrm{mg} \mathrm{kg}^{-1}$ ) (Alary and DemougeotRenard, 2008). The maintenance of waterways such as the Scarpe river by regular dredging generates large volumes of metal-polluted sediments. Land disposal of these sediments may present some risks in the environment. Sediments with contaminant levels above guidelines are usually stored in landfill sites. Over the last decade, a substantial body of research has been conducted on the fate of metals in the lower Scarpe river. Studies have focussed on the speciation of Zn (Isaure et al., 2002; Isaure et al., 2005) and other metals (Thiry et al., 2002) and on their availability (Piou et al., 2009; Lions et al., 2010). Chemical extractions suggested that $\mathrm{Cd}$ was mostly present in the oxidable fraction, likely polymetallic sulfides, but no direct methods such as EXAFS spectroscopy was used to determine $\mathrm{Cd}$ overall speciation in this sediment. Chemical extractions suggested that after land disposal of the sediment, the sulfidic pool progressively decreased in favour of exchangeable forms (Piou et al., 2009). Secondary $\mathrm{Cd}$ species formed after release of $\mathrm{Cd}^{2+}$ in a soil may include O-coordinated $\mathrm{Cd}$ adsorbed to iron oxihydroxides, clay minerals, carbonates and $\mathrm{COOH} / \mathrm{OH}$ groups of organic matter, and $\mathrm{S}$-coordinated $\mathrm{Cd}$ complexed by reduced organic $\mathrm{S}$ groups of natural organic matter or bacterial cell walls or Cd adsorbed to metal sulfides (O'Day et al., 1998; Karlsson et al., 2005, 2007; Sajidu et al., 2008; Mishra et al., 2010; Fulda et al., 2013). To our knowledge, there is no study on $\mathrm{Cd}$ speciation in dredged sediments after land disposal using direct methods.

Phytotechnologies have been proposed as alternative management methods for these sediments (Bert et al. 2009; Bolan et al., 2011). In a previous work, the fate of $\mathrm{Zn}$ after a phytostabilization treatment with graminaceous plants was studied (Panfili et al, 2005). Results showed a clear impact of the rhizospheric activity on $\mathrm{Zn}$ speciation, regardless of the plant species (Festuca rubra or Agrostis tenuis) and of the addition of amendments. $\mathrm{Zn}$ sulfide, present as major $\mathrm{Zn}$ species in the original sediment, was almost completely oxidized and replaced by secondary forms including $\mathrm{Zn}$ phosphate, $\mathrm{Zn}$ phyllosilicates and $\mathrm{Zn}$-sorbed ferrihydrite. The rhizosphere is a zone of intense and dynamic exchanges between the soil, the root, and the microbial and fungal communities which colonize this zone. Exchanges in gas, water, solutes, large and small organic molecules are supposed to influence the chemistry of metals, although it is difficult to know exactly the role of each parameter in this complex interplay (Hinsinger et al., 2006; Wenzel 2009). The rhizosphere of metal hyperaccumulating plants has been the subject of many studies. Enhanced metal uptake by these species does not seem to be related to specific phenomena, but to the enhancement of processes common with non-accumulators. They include a highly developed root system, enhanced transport activity 
at the soil-root interface, and possibly enhanced release (or release of different types) of organic ligands (Wenzel, 2003; Li et al., 2013, Tsednee et al., 2014). A. halleri is a model of $\mathrm{Zn}, \mathrm{Cd}$ hyperaccumulating plant, and it has been intensively studied for the genetics and physiology of metal tolerance and hyperaccumulation (Roosens et al., 2008; Sarret et al., 2009; Huguet et al., 2012; Verbruggen et al, 2013; Isaure et al., 2015; Meyer et al., 2015). It is a pseudo-metallophyte, which means that it is found both on metal-rich and normal environments. Previous studies suggested some variations in metal tolerance and accumulation between and within populations (Meyer et al., 2010; Meyer et al. 2015). Despite these numerous studies, data concerning the impact of $A$. halleri on the speciation and availability of $\mathrm{Cd}$ in the soil are lacking.

The aim of this work was to determine the speciation of $\mathrm{Cd}$ in a dredged sediment, to assess its fate after land disposal, and to evaluate the influence of the rhizospheric activity on $\mathrm{Cd}$ speciation. The $\mathrm{Cd}$ tolerant and hyperaccumulating species A. halleri was chosen as model plant for this study because this species is naturally present in metal-contaminated soils of this studied area. Moreover, we have some knowledge on $\mathrm{Zn}$ and $\mathrm{Cd}$ tolerance and accumulation (Sarret et al., 2009 and Isaure et al., 2015, respectively), and on rhizospheric processes (Barillot et al., 2013) for A. halleri from the same metallicolous origin. Thus, this species was not chosen as a candidate for phytoextraction (which it is not), but as a model plant to study rhizospheric processes.

Information on $\mathrm{Cd}$ solid phase speciation, on $\mathrm{Cd}$ extractability and leachate composition, and on $\mathrm{Cd}$ transfer in the plant was obtained. Such combined approach provides key information on metal dynamics in soil-plant system both on the short and long term. Such knowledge is essential for the management and phytomanagement of dredged sediments after land disposal. In this aim, a 5-month pot experiment was conducted on a $\mathrm{Zn}$ - and Cd-contaminated dredged sediment with $A$. halleri of two origins, metallicolous (MET) and non-metallicolous (NMET). Plants originating from a contaminated site and a non contaminated site were compared to examine potential differences between MET and N-MET plants in Cd uptake and $\mathrm{Cd}$ behaviour in rhizosphere. The speciation of cadmium in the sediment before and after culture and its relationships with other elements were studied by a combination of bulk and microanalyses including scanning electron microscopy coupled with energy dispersive spectroscopy (SEM-EDS), micro X-ray fluorescence ( $\mu \mathrm{XRF}$ ) coupled with $\mathrm{Cd} \mathrm{L}_{\mathrm{III}}$-edge and $\mathrm{S}$ $\mathrm{K}$-edge micro X-ray absorption near edge structure ( $\mu$ XANES) spectroscopy, and bulk Cd Kedge extended X-ray absorption fine structure (EXAFS) spectroscopy. The mobility and bioavailability of cadmium in the sediment were studied by $\mathrm{Ca}\left(\mathrm{NO}_{3}\right)_{2}$ extractions and 
diffusive gradient in thin films (DGT), and measurement of Cd content in the leachates. In addition, plant growth parameters and $\mathrm{Cd}$ accumulation were monitored.

\section{Materials and methods}

\subsection{Sediment}

The sediment was collected from the lower Scarpe river in the North of France (about $30 \mathrm{~km}$ south of Lille). In this study, $500 \mathrm{~kg}$ of surface sediment from an area containing $150 \mathrm{mg} \mathrm{kg}^{-1}$ Cd (Alary, 2001) were dredged with a mechanic shovel. The sediment was then mixed, spread as a $20 \mathrm{~cm}$-thick layer and dried outdoor for 7 months until the water content was $20 \%$ in mass. The sediment was mechanically homogenized several times and sieved $(<5 \mathrm{~mm}$ with a Cross Beater Mill SK - RETSCH). Characteristics of the sediment at this time, "initial time" $t i$ (Fig. 1), just before plant culture, are given in Table 1. Particle size distribution was analyzed following methods described in Isaure et al. (2002). Pseudo-total elements concentrations $(\mathrm{Cd}, \mathrm{Zn}, \mathrm{Cu}, \mathrm{Pb}, \mathrm{Ni}$, and $\mathrm{As})$ were quantified in sediment and in the different granulometric fractions. Aliquots of $0,5 \mathrm{~g}$ of samples were dried and sieved $(100 \mu \mathrm{m})$ and then digested by aqua regia micro-waves assisted dissolution. Metal concentrations were determined by ICP-AES. Quality control was based on the use of sediment certified standard samples (NWRI TH-2) and internal control samples.

The $\mathrm{pH}$ of the sediment before culture was about $7.48 \pm 0.01$. The sediment was relatively rich in organic matter and had a relatively high cation exchange capacity (Table 1). As expected the metal concentrations in sediment were high with $141 \pm 24 \mathrm{mg} \mathrm{kg}^{-1} \mathrm{Cd}$, and other metals (Table 1). The Cd content was higher in finest fractions (e.g. $290 \pm 10 \mathrm{mg} \mathrm{kg}^{-1} \mathrm{Cd}$ for $<2 \mu \mathrm{m}$ fraction). Sediment was mainly composed by $<50 \mu \mathrm{m}$ fractions (Table 1), which concentrated $72 \% \mathrm{Cd}$.

\subsection{Plant material}

A. halleri develops natural populations on both metal contaminated and uncontaminated soils in Europe (Bert et al., 2002). Viable seeds of A. halleri were collected in a smelter-impacted site (Bois des Asturies - Auby, France) and in an uncontaminated site (Hautes Fagnes, Belgium). The soil of Bois des Asturies has been characterized in several studies (Bert et al., 2000; Cuny et al., 2004; Sarret et al., 2004; Pauwels et al., 2006; Farinati et al., 2011; Gomez- 
Balderas et al. 2014). The data from Sarret et al. (2004) are given in Figure SI-1. The topsoil (0-20 cm) in which $A$. halleri developped roots was collected, and characterized as previously described for the sediment (Fig. SI-1).

\subsection{Pot experiment}

After vernalisation, A. halleri seeds were germinated on filter papers moistened with deionized water. Seedlings were transferred to pots filled with compost and grown for 4 weeks. Just before transfer on sediment (at $t i$ - Fig. 1), metals concentrations in aerial parts of A. halleri seedlings of both origins were analysed. Seedlings of A. halleri from metallicolous (MET) and non metallicolous (N-MET) origin were transferred to $4 \mathrm{~L}$ pots containing $2,8 \mathrm{~kg}$ of $5 \mathrm{~mm}$-sieved sediment after roots had been washed carefully with deionised water. The monitoring of the culture was started after a 3-weeks period of adaptation to the new substrate (at $t_{0}$ ). Non vegetated pots were used as control, and each vegetated pot contained one seedling. A total of 39 pots were used, including 3 for the control and 18 for each origin of $A$. halleri (a triplicate for each sampling time, $t_{0}$ to $t_{5}$ ). Sediment moisture was maintained at $80 \%$ field water capacity by regular addition of deionised water. Plants were grown for five months in controlled conditions $\left(12 \mathrm{~h}\right.$ photo period, $20 / 16^{\circ} \mathrm{C}$ day/night temperature, $80 \%$ relative humidity) and pots were moved randomly each week.

\subsection{Microscopic and spectroscopic analyses of the sediment before and after culture}

Cd localization in the sediment was studied by SEM-EDS and $\mu$ XRF. Cd speciation was studied by $\mathrm{Cd} \mathrm{K}$-edge bulk EXAFS spectroscopy and $\mathrm{Cd}_{\mathrm{III}}$-edge $\mu$ XANES spectroscopy, and $\mathrm{S}$ speciation was determined by $\mathrm{S}$ K-edge $\mu$ XANES spectroscopy.

\subsubsection{Sample preparation}

Undisturbed blocks of sediments were collected from the pots before and after culture with MET and N-MET plants. Rhizosphere blocks were then freeze-dried, impregnated with epoxy resin, and prepared as $30 \mu \mathrm{m}$-thick micro-polished thin sections for electron and X-ray analyses (SEM-EDS, $\mu$ XRF and $\mu$ XANES). For bulk analyses, other blocks from pots with or without plant were collected. Roots were removed, and the substrate was freeze-dried, ground and pressed as pellets. 


\subsubsection{Reference compounds}

The XANES and EXAFS analysis was based on a large database of reference Cd-containing compounds. They included commercial $\mathrm{Cd}$ minerals, Cd-containing compounds prepared at the laboratory and natural samples. Purchased chemicals used were all ACS reagent or analytical grade quality. The database included $\mathrm{CdS}, \mathrm{CdCl}_{2}, \mathrm{CdCO}_{3}, \mathrm{Cd}\left(\mathrm{NO}_{3}\right)_{2}, \mathrm{CdO}$, $\mathrm{Cd}(\mathrm{OH})_{2}$, Cd-phosphate $\left(\mathrm{Cd}_{5} \mathrm{H}_{2}\left(\mathrm{PO}_{4}\right)_{4}, 4 \mathrm{H}_{2} \mathrm{O}\right), \mathrm{CdSO}_{4}, \mathrm{Cd}$-sorbed goethite and Cd-sorbed ferrihydrite containing $\sim 8000 \mathrm{mg} \mathrm{kg}^{-1} \mathrm{Cd}$ kindly provided by A. Voegelin (Fulda et al., 2013), and a mixed sulfide $(\mathrm{Zn}, \mathrm{Cd}, \mathrm{Fe}) \mathrm{S}$ extracted from a metamorphic rock was used as well. It was composed of sphalerite enriched in $\mathrm{Cd}$ and $\mathrm{Fe}$ (XRD spectrum in Figure SI-2 - Cd content: $1350 \mathrm{ppm}$ ). In addition, a library of Cd-organic complexes including Cd-malate, $\mathrm{Cd}$ citrate, Cd-succinate, Cd-alginate, Cd-histidine, Cd-cysteine, Cd-glutathione, Cd-PC2, Cdoxalate, Cd-cellulose, Cd-pectin, already described by Isaure et al. $(2006,2015)$ and Huguet et al. (2012) was used. Two more reference compounds included Cd with three organic acids in solution $(\mathrm{Cd}-\mathrm{OAs}, 5 \mathrm{mM} \mathrm{Cd}, 14 \mathrm{mM}$ citrate, $100 \mathrm{mM}$ malate and $400 \mathrm{mM}$ succinate at $\mathrm{pH}=5.5$ - concentrations were chosen according to PHREEQC calculation to have equivalent concentrations of $\left(\mathrm{Cdsuc}_{2}\right)^{2-}, \mathrm{Cdsuc},\left(\mathrm{Cdcit}_{2}\right)^{4-},(\mathrm{Cdcit})^{-}, \mathrm{Cd}^{2+}, \mathrm{Cdmal}$ complexes$)$; and free $\mathrm{Cd}^{2+}\left(10 \mathrm{mM} \mathrm{Cd}^{2+}\right.$ at $\left.\mathrm{pH}=2.2\right)$. Solid state references were diluted in boron nitride and pressed as $5 \mathrm{~mm}$ diameter pellets. All solutions reference compounds were mixed with $20 \%$ glycerol to prevent ice crystal formation during cooling. Spectra for all Cd-containing references were recorded at $\mathrm{Cd} \mathrm{K}$-edge and $\mathrm{L}_{\mathrm{III}}$-edge. For $\mathrm{S}$ K-edge XANES analyses, the database presented in Sarret et al. (1999) was used.

\subsubsection{Data acquisition}

Micro-analyses were performed on thin sections of sediment samples. Cd-rich regions and geochemical associations were first investigated by environmental SEM-EDS. For the sediment before culture, we used a Quanta 200, FEI interfaced with a RONTEC single Drift detector. The chamber pressure was 0.45 Torr and the accelerating voltage $20 \mathrm{kV}$. Ten Cdrich regions areas were identified. For the sediment after culture, we used a Hitachi S-4300 environmental scanning electron microscope with Thermo Ultradry Silicon Drift detector, using an acceleration voltage of $20 \mathrm{kV}$ and pressure was 3990 Torr (30 Pa). Twelve Cd-rich regions areas were analyzed (6 for sediment with MET plants and 6 for sediment with NMET plants). $\mu$ XRF and $\mu$ XANES analyses were performed on beamline LUCIA (SLS, Villigen, Switzerland) equipped with Si (111) crystals and a SDD fluorescence detector, with a beam size of $2.5 \times 5 \mu \mathrm{m}$ on the sample and at room temperature. Regions of interest 
identified by SEM were mapped by $\mu$ XRF before recording Cd LIII-edge (3538 eV) and S Kedge $(2472 \mathrm{eV}) \mu \mathrm{XANES}$ spectra. For each sample, 6 to 8 XANES scans of 20 min were averaged. Cd LiII-edge and S K-edge XANES spectra were also recorded in unfocused mode on various $\mathrm{Cd}$ - and S-containing references (see above). For reference compounds, 2 to 3 spectra were averaged.

Cd K-edge bulk EXAFS measurements were performed on sediment samples on the beamline FAME (BM30B - Proux et al., 2006) at the European Synchrotron Radiation Facility (ESRF, Grenoble, France) equipped with a Si (220) double crystal monochromator. Pellets of sediment samples and reference compounds (pellets and solutions) were transferred in a liquid $\mathrm{He}$ cryostat cooled to $15 \mathrm{~K}$. Spectra were recorded in fluorescence mode using a 30-element solid-state Ge detector (Canberra). For each sample, 10 to 17 scans of 40 min were averaged.

\subsection{4 $\mu \mathrm{XRF}$ and XAS data treatment}

For $\mu \mathrm{XRF}$ elementary maps, fluorescence intensities were normalized by the incident photon intensity (I0) and counting time. XAS spectra were treated using ATHENA (Ravel, 2009) software. The calibration of energy was done using a metal foil reference by setting the first inflexion position of Cd-metal XANES spectrum to the tabulated value of $26711 \mathrm{eV}$; the contribution of the matrix was subtracted and a normalization of signal was done using a linear or a two-degree polynomial. The extracted EXAFS was then $k^{3}$-weighted to enhance the high- $k$ region, and Fourier-transformed (FT) over the $k$ range 3.0 to $10.5-13 \AA^{-1}$, depending on the level of noise. The proportions of $\mathrm{Cd}$ species in sediment samples were obtained by least-squares fitting of recorded spectra to linear combinations of reference spectra from a library of $\mathrm{Cd}$ model compounds including $\mathrm{Cd}$-substituted and $\mathrm{Cd}$-sorbed minerals and Cd-complexed organic compounds (see above). For each spectrum, LCFs using one, two and three components were tested successively. The fit with $n+1$ components was retained if the normalized sum-squares residual (NSS $\left.=\sum\left[k^{3} \chi_{\text {exp }}-k^{3} \chi_{\mathrm{fit}}\right]^{2} \sum\left[k^{3} \chi_{\text {exp }}\right]^{2} 100\right)$ was decreased by more than $10 \%$ as compared to the fit with $n$ components. Percentages of $\mathrm{Cd}$ species are given as average and standard deviations presented are the average over satisfactory fits, defined by NSS comprised between the value obtained for the best fit $\left(N S S_{\text {best }}\right)$ and $1.1 N S S_{\text {best }}$.

In parallel, from $k^{3}$ EXAFS spectra, the structural parameters for $\mathrm{Cd}$ reference compounds and sediment samples were determined by shell simulations using ARTEMIS (Ravel \& Newville, 2005). Phase and amplitude functions were calculated by FEFF 6.0 using the structure of greenockite (CdS) and cernyite $\left(\mathrm{Cu}_{2}\left(\mathrm{Cd}_{0.37} \mathrm{Zn}_{0.33} \mathrm{Fe}_{0.29}\right) \mathrm{SnS}_{4}\right)$ (Szymanski, 1978), Cd-organic 
structures from the Cambridge Structural Database (CSD, Bruno et al., 2002) and the structure of $\mathrm{Cd}_{5} \mathrm{H}_{2}\left(\mathrm{PO}_{4}\right)_{4}, 4 \mathrm{H}_{2} \mathrm{O}$. EXAFS spectra were Fourier transformed over a $k$ range of 3.2-11 $\AA$ for sediment samples, and the contribution of the first shell was simulated in $R$ space, either with $\mathrm{O}$ atoms only, or with $\mathrm{O}$ and $\mathrm{S}$ atoms.

S K-edge XANES spectra were treated by LCFs as described above. S reference compounds were grouped into three families: mineral sulfides (including $\mathrm{CdS}$ and $(\mathrm{Zn}, \mathrm{Cd}, \mathrm{Fe}) \mathrm{S}$ ), organic sulfides (including R-SH, R-S-R and R-S-S-R groups) and oxidized sulfur (including sulfoxides, sulfone, sulfonic acid, and sulfates).

\subsection{Monitoring of $\mathrm{Cd}$ in sediment, plant and leachates}

A monthly monitoring of the sediment, plants and leachates was performed for five months. Each month, three pots per condition were removed from the experiment for the analysis of the sediment and plant. The sediment was separated manually from the roots, sieved $(<2$ $\mathrm{mm}$ ), and total metals concentrations, $\mathrm{pH}$, total carbon (TC) and metals exchangeable and phytoavailable pools were measured on triplicates.

The $\mathrm{Ca}\left(\mathrm{NO}_{3}\right)_{2}$ exchangeable pool was measured according to (Bert et al. 2012). After sieving $(<2 \mathrm{~mm})$ and drying the sediment at $60^{\circ} \mathrm{C}, 10 \mathrm{~g}(\mathrm{DW})$ were shaken in $20 \mathrm{~mL} \mathrm{Ca}\left(\mathrm{NO}_{3}\right)_{2} 0.01$ $\mathrm{N}$ (analytical quality in ultrapure water) for 48 hours at room temperature. After centrifugation $(20 \mathrm{~min}$ at $1200 \mathrm{~g})$, filtration $(0.45 \mu \mathrm{m})$, and acidification of the supernatant ( $0.5 \mathrm{~mL}$ of concentrated, supra-pure nitric acid), metal concentrations were determined by ICP-AES.

Metals phytoavailability was estimated by diffusive gradient in thin film (DGT) probes (Zhang et al., 2001, Nolan et al., 2005). DGT devices loaded with a $0.4 \mathrm{~mm}$ resin gel layer (chelex gel), a $0.7 \mathrm{~mm}$ diffusive gel layer (polyacrylamide gel, restrictive pore) and a 0.13 mm filter (cellulose nitrate) were provided by DGT Research Ltd. $100 \mathrm{~g}$ of sieved sediment were wet to $100 \%$ field water capacity, manually mixed to make a smooth paste, and finally shaken for 3 days. DGT were pressed gently onto the surface of the sediment and placed for $17 \mathrm{~h}$ between $20^{\circ} \mathrm{C}$ and $24^{\circ} \mathrm{C}$. Metal analyses and determination of $\mathrm{C}_{\mathrm{DGT}}$ were made by ICPMS or AAS by DGT Research Ltd.

Plant aspects were examined and rosette diameters were measured on a monthly basis. Besides, on monthly removed pots, three plants of each origin were harvested to analyze their 
aboveground parts (biomass and metals concentrations). Aerial parts were washed with deionised water, oven-dried at $40^{\circ} \mathrm{C}$ until constant weight, then biomass was weighed, ground and homogenized to prepare one aliquot per pot. Total concentrations of $\mathrm{Cd}$ in plant tissues were determined after digestion of $1 \mathrm{~g}$ dry matter in $10 \mathrm{ml}$ of $\mathrm{HNO}_{3}$ and $3 \mathrm{ml}$ of $\mathrm{H}_{2} \mathrm{O}_{2}$, in a microwave oven. Solutions were filtered, adjusted to $100 \mathrm{ml}$ with Milli-Q® water and stored at $4^{\circ} \mathrm{C}$ before analysis. Cd concentrations in the digests were determined by ICP-AES. Spinach leaves samples (SRM 1570a) were used as certified standard.

The monitoring of leachates was performed monthly on the same three pots (cultivated or not). Leachates were collected at the bottom of the pots after the substrate (cultivated and non-cultivated) had been watered with $1 \mathrm{~L}$ of deionised water, delivered in small volumes $(200 \mathrm{~mL})$. Leachates were collected for 2 hours after watering. Leachates were filtered $(0.45$ $\mu \mathrm{m}$ ), then aliquots of $10 \mathrm{~mL}$ were acidified with $\mathrm{HNO}_{3}$ (suprapur ${ }^{\circledR}$ ) and stored at $4^{\circ} \mathrm{C}$ before analysis. Metals concentrations were determined by ICP-AES for which quality control was based on the use of internal control samples.

Statistic analysis was performed using two and one-way ANOVA followed by post hoc comparison using Tukey's test for comparison of individual means (statistical program SPSS $15.0(2007))$.

\section{Results}

\subsection{Cd speciation in the sediment before and after culture of A. halleri}

\subsubsection{Average Cd speciation by Cd K-edge bulk EXAFS spectroscopy}

The speciation of $\mathrm{Cd}$ in the sediment before and after culture was examined by EXAFS spectroscopy. Representative Cd K-edge EXAFS reference spectra used for the linear combination fits are shown in Figure 2. Figure 3 shows the sediment spectra and LCFs results. The spectrum for the sediment before culture was correctly reconstructed with $100 \%$ (Zn, Cd, Fe)S (Fig. 3). Adding a second component did not improve significantly the fit (not shown). Thus, Cd was mainly present as a mixed metallic sulfide. Spectra for the sediment after culture with $A$. halleri MET and N-MET, and for the control (i.e. non vegetated) sediment were similar, although the later presented slightly lower amplitude oscillations, in particular at $11 \AA^{-1}$ (Fig. 3A). Cd in the non vegetated pot was present as $74 \pm 2 \% \mathrm{Cd}$ - 
Organic acids, $22 \pm 1 \% \mathrm{Cd}$-phosphate and $8 \pm 1 \% \mathrm{Cd}$ as mixed sulfide ((Zn, Cd, Fe)S - Fig. 3B). Removing this later species increased the fit residual by $11 \%$. Thus, although the proportion of $\mathrm{Cd}$ mixed sulfide is within the precision of the method as generally estimated $( \pm$ $10 \%$ ), its contribution may be significant in the present case. At the opposite, spectra for vegetated sediment were correctly fitted with a combination of Cd-organic acids $64 \pm 5 \%$ and $61 \pm 16 \%$ for MET and N-MET respectively) and Cd-phosphate (34 $\pm 2 \%$ and $30 \pm 16 \%$ respectively). These results evidence changes in $\mathrm{Cd}$ speciation during the pot experiment. $\mathrm{Cd}$ sulfide was almost completely oxidized in the absence of plants, and secondary phases including $\mathrm{Cd}$-organic complexes and $\mathrm{Cd}$ phosphate were formed. The same process was observed in the presence of plants, but the removal of $\mathrm{Cd}$ sulfide was total and the proportion of Cd-phosphate increased. There was no influence of the origin (MET or N-MET) of $A$. halleri on Cd speciation in the substrate.

Structural parameters for $\mathrm{Cd}$ in the sediment and several representative $\mathrm{Cd}$ reference compounds were then determined by shell fitting (Fig. 4, Table 2). For CdS, Cd-phosphate and $\mathrm{CdCO}_{3}$, structural parameters were consistent with the XRD structures (Huguet et al., 2012). For ( $\mathrm{Zn}, \mathrm{Cd}, \mathrm{Fe}) \mathrm{S}$, the first shell of coordination was simulated by $4 \mathrm{~S}$ atoms at $2.52 \AA$, as in CdS structure, and the second shell by a mixture of Fe, $\mathrm{Zn}$ and $\mathrm{Cd}$ atoms (Table 2, Fig. SI-3). As expected, the same type of environment was obtained for the sediment before culture. Fit with Cd only as next nearest neighbour was not satisfactory (Fig. 4B). Based on the $\mathrm{Fe}, \mathrm{Zn}, \mathrm{Cd}$ coordination numbers $(0.3,4.8$ and 2.2 , respectively, Table 2$)$, it can be concluded that $\mathrm{Cd}$ was present as a mixed sulfide containing about $2 / 3 \mathrm{Zn}, 1 / 3 \mathrm{Cd}$ and traces of $\mathrm{Fe}$. The sum of $\mathrm{Zn}, \mathrm{Cd}$ and $\mathrm{Fe}$ contributions was 7.3 atoms, i.e. significantly lower than the 10 atoms in $\mathrm{CdS}$ or $\mathrm{ZnS}$ structure, but like in the (Fe $\mathrm{Zn} \mathrm{Cd}) \mathrm{S}$ reference, i.e. about 8 neighbours in the second shell. This difference likely reflects some structural disorder, probably due to the presence of metals with very different ionic radii in the crystal lattice, and/or to the presence of non-equivalent crystallographic sites for $\mathrm{Cd}$. The Fourier transformed spectra for the sediments after the pot experiment showed a first shell at a distance typical of oxygen ligands, and almost no second shell peak (Fig. 4B). For the vegetated pots, fit results gave 6-7 O atoms at 2.29-2.3 $\AA$ (Table 2). For the non vegetated pot, a minor contribution of S atoms was found, which is consistent with LCFs results. Due to the very low amplitude, no significant signal was observed for $\mathrm{R}+\Delta \mathrm{R}>2.5 \AA$ : no second shell was needed for the simulation.

\subsubsection{SEM-EDS, micro-XRF and Cd- $\mathrm{L}_{\text {III }}$ edge and $\mathrm{S}-\mathrm{K}$ edge $\mu \mathrm{XANES}$ analyses}


Micro-scale investigations were performed to observe geochemical associations, weathering processes of $\mathrm{Cd}$ sulfide grains, and to identify possible minor forms of $\mathrm{Cd}$ in sediment before and after culture. SEM-EDS enabled the localization of Cd-rich regions in various types of grains. A representative coarse grain of the sediment before culture is shown in Figure 5, and two representative grains for the sediment after culture are shown in Figure 6. For the sediment before culture, metal-rich areas were localized at the edge of the grain (Fig. 5A, B). The $\mathrm{Cd}$ richest region contained $\mathrm{Zn}$ and $\mathrm{S}$ as major elements (40 and $31 \%$ in atomic $\%$ based on the EDS calculated composition), as well as $\mathrm{Si}(12 \%), \mathrm{Al}(6.9 \%), \mathrm{Mg}(3.1 \%), \mathrm{Cd}, \mathrm{Ca}$ and $\mathrm{Na}(1.8 \%), \mathrm{Fe}(1.1 \%)$. These results suggest the presence of $\mathrm{Zn}$ sulfide containing impurities of $\mathrm{Cd}$ and $\mathrm{Fe}$, associated with aluminosilicates nanoparticles. These findings are consistent with bulk EXAFS results. Other regions contained more diffuse $\mathrm{Cd}$ concentrations around Cd-rich spots. Two spots were selected for $\mu$ XANES analyses, the $\mathrm{Cd}$ rich spot described above ( $\mathrm{P} 2$, with $\mathrm{S} / \mathrm{Cd}$ fluorescence intensity ratio $=8$ and $\mathrm{P} / \mathrm{Cd}=0.4$, Fig. $5 \mathrm{~B})$, and a spot with more diffuse $\mathrm{Cd}$ concentration ( $\mathrm{P} 1$, with $\mathrm{S} / \mathrm{Cd}=21$ and $\mathrm{P} / \mathrm{Cd}=0.8$, Fig. $5 \mathrm{~B}$ ). $\mathrm{Cd} \mathrm{L}_{\mathrm{III}}$ edge $\mu$ XANES spectra recorded on the bulk sediment, on P2 and P1 are shown in Figure 7. They show a smooth edge characteristic of S ligands (Isaure et al., 2006). They were all fitted with $100 \% \mathrm{Cd}$ sulfide species. ( $\mathrm{Zn}, \mathrm{Cd}, \mathrm{Fe}) \mathrm{S}$ was the only component for the bulk sediment and the $\mathrm{Cd}$ richest spot ( $\mathrm{P} 2)$, whereas Cd-thiols (Cd-organic sulfides) were present as additional component in P1 (Fig. 9). Figure 7 shows that the spectrum for Cd-thiol has some similarities with $\mathrm{CdS}$ and $(\mathrm{Zn}, \mathrm{Cd}, \mathrm{Fe}) \mathrm{S}$, but is smoother.

In addition, $\mathrm{S}$ K-edge $\mu$ XANES were recorded in the bulk sediment and on P1 and P2 spots to investigate $\mathrm{S}$ oxidation state (Fig. 8). They all showed a first peak at $2473 \mathrm{eV}$, characteristic of reduced S (Fig. 8). In addition, P1 shows a peak at $2482 \mathrm{eV}$ (Fig. 8) characteristic of oxidized S. Three families were distinguished by LCFs, including mineral sulfides, organic sulfides and oxidized S species. Mineral sulfides dominated in the bulk and in P1 and P2 spots, organic sulfides represented minor species in P1 and P2 spots, and oxidized species represented $4 \%$ (in the bulk) to $12 \%$ (in P1 - Fig. 9).

Two representative grains for the sediment after culture showed reddish brown area around the grains that indicated the presence of oxidized Fe (Fig. 6A). SEM-EDS analyses showed that $\mathrm{Cd}$-rich region contained also $\mathrm{S}, \mathrm{Fe}, \mathrm{Zn}, \mathrm{Si}, \mathrm{Al}$ and $\mathrm{P}$ in various proportions (Fig. 6B). Micro-XRF maps allowed to localize the $\mathrm{Cd}$ most concentrated spot previously identified by SEM and to visualize more precisely the chemical associations. The $\mathrm{Cd}$ richest spot, P3A, contained also $\mathrm{S}$ and $\mathrm{P}$ (Fig. 6B). Another Cd-rich spot, $\mathrm{P} 3 \mathrm{~B}$, was less rich in $\mathrm{S}$ and $\mathrm{P}$ than 
P3A (Fig. 6B). The spot P3C contained less Cd (Fig. 6B). The second representative grain shows a zone with diffuse $\mathrm{Cd}$ co-localized with $\mathrm{P}$, and to a lesser extent with $\mathrm{S}$ (spot P4, Fig. 6C). The $\mathrm{Cd} \mathrm{L}_{\mathrm{III}} \mu \mathrm{XANES}$ spectra for P3A and P3B were similar to P1 and P2, whereas P3C and $\mathrm{P} 4$ spectra presented a pre-peak at $3538 \mathrm{eV}$ characteristic of Cd-O bond (Fig. 7). Based on LCFs, the Cd richest spots (P3A and P3B) contained a majority of Cd sulfides and 15 to 25 $\% \mathrm{Cd}$ Cd-organic acids, whereas the more diffuse zones (P3C and P4) contained $\mathrm{Cd}$-organic acids and Cd-phosphate as major species (80 and $100 \%$, respectively - Fig. 9). Thus, $\mathrm{Cd}$ speciation drastically changes from $\mathrm{P} 3 \mathrm{~B}$ to $\mathrm{P} 3 \mathrm{C}$ which are distant of about $50 \mu \mathrm{m}$. The presence of $\mathrm{Cd}$ phosphate is consistent with the high $\mathrm{P}$ signal in spot $\mathrm{P} 4$. The chemical state of $\mathrm{S}$ as determined by $\mathrm{S}$ K-edge XANES showed an increase in oxidized $\mathrm{S}$ species following the increase in $\mathrm{Cd}-\mathrm{O}$ species. The spot containing the higher amount of oxidized S is $\mathrm{P} 4$, with 34 \% (Fig. 9). In this spot, Cd-S species were completely replaced by Cd-O species. Thus, other sulfide species, more resistant to oxidation than the one hosting $\mathrm{Cd}$, are still present. Again, spots distant of $50 \mu \mathrm{m}$ only showed very different $\mathrm{S}$ speciation. These results were obtained on the sediment vegetated with MET plants. Very similar results were obtained with N-MET plants, therefore these results are not presented here.

To conclude, the persistence of $\mathrm{Cd}$ sulfide species in some $\mathrm{Cd}$ rich spots was observed in the sediment after culture. These species represent less than $10 \%$ of total $\mathrm{Cd}$ since they were not detected by bulk XAS. In addition, a large variety of S oxidation states was observed, but reduced $\mathrm{S}$ dominated, even in spots where $\mathrm{Cd}$ sulfides species had been oxidized.

\subsection{Cd exchangeability and leaching}

XAS is not very sensitive to weakly sorbed species, and it is useful to evaluate in parallel the exchangeable and bioavailable pool at the macroscopic scale by physico-chemical approaches. Cd pseudo-total concentration in sediment before culture was about $140 \mathrm{mg} \mathrm{kg}^{-1}$ (Tab.1) and was not significantly different than those measured in sediment during and after culture with MET or N-MET plants and in control pots, i.e. without plant (not shown). However, after culture, a decrease of approximately $0.6 \mathrm{pH}$ unit was observed in pots with plants (regardless their origin) and in control pots (ANOVA 1 factor $\mathrm{P}>0.05$ - not shown). Indeed the $\mathrm{pH}$ measured before culture in sediment at $7.48 \pm 0.01$ (Tab.1) was then measured at $6.86 \pm 0.22$, $6.95 \pm 0.03$ and $6.81 \pm 0.02$ for MET, N-MET and control pot respectively. Decrease in $\mathrm{pH}$ measurement was not a plant effect. It was probably correlated with oxidation of metallic sulfides in sediment. 
For the sediment before culture, $\mathrm{Ca}\left(\mathrm{NO}_{3}\right)_{2}$-extractable $\mathrm{Cd}$ concentration was $1.02 \pm 0.1 \mathrm{mg}$ $\mathrm{kg}^{-1}$ DW (Fig. 10A). At the end of the monitoring, this parameter decreased significantly in the control pot $\left(\mathrm{P}<0.05,0.71 \pm 0.03 \mathrm{mg} \mathrm{kg}^{-1} \mathrm{DW}\right.$ at $t_{6}$ for control pot, Fig. 10A). For vegetated pots, extractable $\mathrm{Cd}$ concentrations measured monthly were significantly different from the sediment before culture, even after only one month $(\mathrm{P}<0.05$, Fig. 10A). However, they were not significantly different from those measured in the control pot at $t_{6}(\mathrm{P}>0.05$, Fig. 10A). Thus, there was no plant effect on $\mathrm{Cd}$ extractable concentrations during culture regardless of $A$. halleri origin.

DGT was used to quantify Cd phytoavailable pool in sediment for some samples (Fig. 10B). $\mathrm{Cd}$ bioavailable concentrations were lower than $\mathrm{Cd}$ extractable concentrations. By comparison with $\mathrm{Cd}$ extractable concentrations, there was no significant difference between bioavailable $\mathrm{Cd}$ in the sediment before culture and in vegetated pots (Fig. 10B). Bioavailable Cd was not measured on pots without plant at the end of the assay.

Thus, the major changes in $\mathrm{Cd}$ speciation observed between the sediment before and after culture did not induce marked changes in Cd exchangeability and bioavailability.

The evolution of $\mathrm{Cd}$ concentrations in leachates was monitored monthly (Fig. 11A). For control pots, $\mathrm{Cd}$ concentrations were not significantly different over time $(\mathrm{P}>0.05-$ Fig. $11 \mathrm{~A})$ : about $0.30 \pm 0.07 \mathrm{mg} \mathrm{L}^{-1}$. By contrast, in vegetated pots $\mathrm{Cd}$ concentrations were lower from $t_{2}$ and then did not vary significantly (Fig. 11A). Thus, the presence of plants seems to decrease Cd concentrations in leachates.

\subsection{Cd transfer in the plant}

The plant biomass was measured monthly. At $t i$, when plants were transferred on sediment, plants of both origins presented similar biomasses, i.e. $3.0 \pm 1.1 \mathrm{~g}$ for MET plants and $3.2 \pm$ $1.7 \mathrm{~g}$ for N-MET (average for $\mathrm{n}=3 \pm \mathrm{SD}$, $(\mathrm{P}>0.05$, test of Student - Fig.11B). Biomasses measured after one month of growth, i.e. at $t_{1}$, were higher than those measured at $t i$ (Fig. 11B). This shows that plants were able to develop on contaminated sediment. No significant increase of biomass was observed for N-MET plants between $t_{1}$ and $t_{5}(\mathrm{P}>0.05$, Fig. 11B), but standard deviations were important. MET plants biomass increased from $t_{1}$ to $t_{3}$ and then decreased ( $\mathrm{P}<0.05$, Fig. 11B). The maximum difference in biomass was observed the third month $(33.1 \pm 4.6 \mathrm{~g}$ for MET), and could be related to a better tolerance of metallicollous 
plants compared to non metallicolous ones (Meyer et al. 2015) as shown for Zn (Meyer et al., 2010). During the fourth month of culture, one part of MET plant leaves began to show drought signs. The decrease in biomass observed at $t_{4}$ and $t_{5}$ could be a response to sediment toxicity.

$\mathrm{Cd}$ concentrations were measured in aerial parts of $A$. halleri at $t i$ as follow: $3.7 \pm 2.4$ and 4.7 $\pm 1.0 \mathrm{mg} \mathrm{kg}^{-1} \mathrm{DW}$ for MET and N-MET plants respectively (Fig. 11C). There was no significant difference between plant origins (Student test: $\mathrm{P}>0.05$ ). From $t_{1}$ to the end of growth, $\mathrm{Cd}$ concentrations were higher than those measured at $t i$. For instance, between $t i$ and $t_{1} \mathrm{Cd}$ concentrations in aerial parts were respectively increased by 30 and 39 times for MET and N-MET. All measured concentrations, except for N-Met at $t_{2}$, reached the hyperaccumulating threshold set to $100 \mathrm{mg} \mathrm{Cd} \mathrm{kg}^{-1} \mathrm{DW}$ (Baker and Brooks, 1989, Wenzel and Jockwer, 1999). For each origin tested separately, no significant variation of $\mathrm{Cd}$ concentrations in aerial parts was observed with time ( $\mathrm{P}>0.05$, Fig. 11C). Maximal $\mathrm{Cd}$ concentrations were $204 \pm 96$ and $185 \pm 18 \mathrm{mg} \mathrm{kg}^{-1}(\mathrm{n}=3 \pm \mathrm{SD}$ ) for, respectively, MET plant at $t_{4}$ and N-MET plant at $t_{l}$ (Fig. 11C). Standard deviations were important, suggesting a high inter-individual variability in $\mathrm{Cd}$ accumulation.

\section{Discussion}

\subsection{Cd speciation in sediment before and after culture of $\boldsymbol{A}$. halleri}

Before culture, $\mathrm{Cd}$ in the sediment was present as a mixed $\mathrm{Cd}, \mathrm{Zn}, \mathrm{Fe}$-sulfide containing about 2/3 Zn, 1/3 Cd and traces of Fe. Cd-containing mixed sulfides were also observed in metalcontaminated marine sediments (O'Day et al.; 1998; Carroll et al., 2002). A previous study on $\mathrm{Zn}$ speciation in the Scarpe sediment showed that $\mathrm{Zn}$ was mostly present as sphalerite (Isaure et al, 2002). Considering that $\mathrm{Zn}$ is 25 to 30 times more concentrated than $\mathrm{Cd}$ in this sediment (Table 1), it is clear that the sediment contains both some mixed Cd,Zn,Fe-sulfides and pure Zn sulfide. This was confirmed by SEM-EDS. Likewise, pure pyrite grains were observed by SEM-EDS (not shown), so $\mathrm{Fe}$ is present both in mixed metallic and pure $\mathrm{Fe}$ sulfide. Polymetallic sulfides may come from the ore which was transported by boat on the river, from atmospheric emissions of the smelters and dissemination of smelter slag (Isaure et al, 2002). They may also be formed during early diagenesis of sediments (Audry et al., 2005). The 
presence of both reduced and oxidized forms of sulfur in the sediment shows that it has been partially oxidized during the drying and preparation procedure.

After 5 months of pot experiment, Cd sulfides were totally (for vegetated pots) and almost totally ( $8 \%$ remaining $\mathrm{Cd}$ sulfides in non vegetated ones) oxidized, and secondary species included Cd-organic acids and $\mathrm{Cd}$ phosphates. Micro analyses confirmed the persistence of $\mathrm{Cd}$ sulfides in some regions of the sediment thin sections. The study of $\mathrm{Zn}$ speciation in dredged sediment from the Scarpe vegetated or not with two Poaceae (Agrostis tenuis and Festuca rubra) showed that after 18 months of culture, $\mathrm{ZnS}$ was almost completely oxidized, whereas half of $\mathrm{Zn}$ was still present as $\mathrm{ZnS}$ in the pot without plant (Panfili et al., 2005). Although plants and conditions differed between the two studies, the comparison of the results suggested a higher sensitivity to oxidation for $\mathrm{Cd}$ than for $\mathrm{Zn}$ in this sediment. Previous studies on mixed metallic sulfides suggested different sensitivities of metals towards oxidation, with preferential release of $\mathrm{Zn}$ relative to $\mathrm{Cd}$ (O'Day et al., 1998; Barret and McBride, 2007). The same tendency was observed in $\mathrm{Zn}, \mathrm{Cd}$-containing soils rich in sulfur (McBride et al., 2006; de Livera et al., 2011). These results are not in contradiction with our results because in the Scarpe sediment, $\mathrm{Cd}$ was mostly present in a mixed $(\mathrm{Zn}, \mathrm{Cd}, \mathrm{Fe})$ sulfide, whereas $\mathrm{Zn}$ was mostly present as pure $\mathrm{ZnS}$. Thus, the change in $\mathrm{Zn}$ speciation in this sediment is controlled by $\mathrm{ZnS}$ much more than by the mixed sulfide. The persistence of reduced $\mathrm{S}$ species in regions of the thin sections where $\mathrm{Cd}$ was bound to $\mathrm{O}$ ligands (see Results) suggests that other metallic sulfides are still present in regions where $\mathrm{Cd}$ has been oxidized.

In the sediment without plant, the oxidation of metallic sulfides may be ascribed to the alternating dry and wet conditions due to watering, which brings oxygen to the system. Barrett and McBride (2007) demonstrated that oxidation of inorganic sulfides to $\mathrm{SO}_{4}{ }^{2-}$ in aerated soil environments proceeded within hours. In a study on $\mathrm{Cd}$ speciation in a paddy soil, Fulda et al. (2013) showed the formation of Cd sulfides under flooded (anoxic) conditions. The CdS crystallites, estimated to be nanometer-sized, were oxidized upon aeration of the system, and the original $\mathrm{Cd}$ speciation, dominated by Cd-carboxyl species, was restored. Like in acid mine drainage environments, the oxidation of metallic sulfides may be catalyzed by microorganisms. Bacteria present in sediments of the Scarpe River have been shown to play an important role in increasing or decreasing metal availability (Lors et al. 2004; Bert et al 2009, 2012). Bert al. (2012) suggested that bioleaching of metals was caused by sulfuroxidizing bacteria whereas anaerobic sulfate-reducing bacteria could precipitate metals. 
In the planted sediment, the oxidation process was slightly higher, although the difference is close to the uncertainty of the method. Several processes taking place in the rhizosphere might explain this oxidation: Plant rooting may increase the penetration of oxygen in the sediment. This effect counterbalances the effect of root respiration which, conversely, causes $\mathrm{O}_{2}$-impoverishment and $\mathrm{CO}_{2}$-enrichment of the rhizosphere (Marschner 1995; Hinsinger et al, 2003). The uptake of water, ions and nutrients and the release of ions and organic ligands by the root and associated organisms (fungi, bacteria) are supposed to affect the chemical equilibria and induce dissolution-reprecipitation and sorption-desorption processes.

In vegetated and non vegetated pots, Cd was mainly associated with phosphates (30-34 and $22 \%$, respectively) and with $\mathrm{COOH} / \mathrm{OH}$ groups of organic matter (61-64 and 74\%, respectively). $\mathrm{Cd}$ phosphate can be considered as a stable species on the long term (Hamon et al., 1998). The role of organic matter in Cd binding in the Scarpe sediment after land disposal was highlighted by Vansimaeys et al. (2009), who evaluated by chemical extractions an increase from 10 to $65 \%$ of organically bound $\mathrm{Cd}$ from the fresh to land deposited, drained sediment. Piou et al. (2009) also suggested an important role of organic matter in the control of the seasonal dynamics of $\mathrm{Cd}$. The binding of $\mathrm{Cd}$ to $\mathrm{COOH} / \mathrm{OH}$ groups of organic matter is consistent with previous findings by Liu et al. (2001) and Fulda et al (2013). Karlsson et al. (2007) identified a mixture of O- and S-containing ligands for $\mathrm{Cd}$ in a peat soil. The association of $\mathrm{Cd}$ with phosphate is not surprising because of the high $\mathrm{P}$ content of the sediment, and high affinity of $\mathrm{Cd}$ for phosphate minerals. The proportion of $\mathrm{Cd}$ phosphate was slightly higher in the vegetated than in the non vegetated pots. This can be related to the rhizosphere activity favouring the mobilization and increasing its availability (Hinsinger et al., 1998). The present EXAFS data do not allow to distinguish Cd-sorbed or coprecipitated phosphate, but both phenomena are likely (Brown et al. (2004).

\subsection{Impact of $\boldsymbol{A}$. halleri culture on $\mathrm{Cd}$ exchangeable pool and leachates}

Although the presence of plants had an impact on Cd speciation in the sediment, they did not influence $\mathrm{Cd}$ exchangeable and phytoavailable pools. Both the $\mathrm{Cd}$ exchangeable and phytoavailable pools did not vary significantly with time for MET and N-MET plants. Low standard deviations indicated low variability between pots for these pools. The relative stability in the exchangeable and phytoavailable pools suggests that $\mathrm{Cd}$ sulfides on one hand, and the mixture of $\mathrm{Cd}$ phosphate and $\mathrm{Cd}$-organic acids on the other hand, display similar exchangeabilities. This result suggest that the Cd-organic acid complexes are weakly 
exchangeable. At the opposite, Zn-organic complexes found in $\mathrm{Zn}$-contaminated organic soil were highly exchangeable (Sarret et al., 2004). The stability of Cd exchangeability during the experiment also suggests that $\mathrm{Cd}$ released by oxidation of sulfides was readily taken up by the secondary phases, with no transient phase with high $\mathrm{Cd}$ availability. The $\mathrm{Cd}$ content in the leachates was very low and the presence of the plant induced a decrease in $\mathrm{Cd}$ concentrations from the second month of culture. This phenomenon can be related to the colonization of the pot by roots and the development of a stable rhizosphere, decreasing the transfer of dissolved and particulate $\mathrm{Cd}$. Plants grown on the sediment contained between 100 to $200 \mathrm{mg} \mathrm{kg}^{-1} \mathrm{Cd}$ DW in their aerial parts. This relatively low $\mathrm{Cd}$ accumulation is consistent with the low $\mathrm{Cd}$ availability and with the fact that $A$. halleri is not a strong Cd hyperaccumulator (Huguet et al., 2012). The lack of difference in Cd solid state speciation, availability and leachability suggests that the rhizospheric activity of both plants have a similar impact on the soil chemistry. Additional data on root exudates, microbial activity and redox potential would be necessary to elaborate more on this point.

\section{Conclusion}

This study assessed the fate of $\mathrm{Cd}$ present in a contaminated dredged sediment during a pot experiment. The combination of chemical analyses and EXAFS spectroscopy allowed to elucidate chemical forms of $\mathrm{Cd}$ in the sediment before and after plant culture. Before culture, $\mathrm{Cd}$ was present as a mixed $\mathrm{Zn}, \mathrm{Cd}$, Fe sulfide. This mixed sulfide was relatively sensitive to oxidation since after 5 months of pot experiment, Cd-bearing sulfides were mostly oxidized in control pots without plants. The presence of Arabidopsis halleri seemed to enhance this process since $\mathrm{Cd}$ sulfides were totally oxidized in vegetated pots. Secondary species including $\mathrm{Cd}$ bound to $\mathrm{O}$-containing groups of organic matter and $\mathrm{Cd}$ phosphates were formed both in vegetated and non vegetated pots. These changes probably occurred via both abiotic and biotic processes, and were enhanced by the plant activity. Despite these changes in speciation, there was no change in $\mathrm{Cd}$ exchangeability or phytoavailability. $\mathrm{Cd}$ phosphate can be considered as stable on the long term. Cd-organic matter complexes may not be stable on the long term, but their presence did not increase $\mathrm{Cd}$ phytoavailability during the experiment. This low availability and low transfer of $\mathrm{Cd}$ to leachates and plants are positive signals in terms of environmental management. A low Cd availability was also observed in the field after land application of the Scarpe sediment (Piou et al., 2009). The presence of plants is 
supposed to give an added value to land disposal because of their role in the limitation of aerial dispersion of contaminants. This study shows that it also has a positive effect on $\mathrm{Cd}$ speciation. However, it is important to consider that $\mathrm{Cd}$ speciation may fluctuate depending on flooding and redox conditions (Piou et al., 2009; Fulda et al., 2013), and that Cd sulfide species may form again under flooded or saturated conditions. Thus, land application and vegetation of the sediment may be an interesting option, provided that the substrate remains unsaturated. .

\section{Acknowledgements}

This work was supported by the Nord-Pas de Calais Region and Voies Navigables de France, FEDER founds through French research program: Programme de Recherche Concertées (PRC "Sites et Sols Pollués, Environnement et Activité Humaines"). ISTerre is part of Labex OSUG@2020 (ANR10 LABX56). Martine Lanson and Vasilica Hammade are acknowledged for their help during chemical analyses. Patrick Degrugilliers is thanked for the preparation of thin sections and Philippe Recourt for his assistance during SEM analyzes. Pierre Lagarde and Nicolas Geoffroy are acknowledged for their assistance during synchrotron experiments. We also thank the ESRF (Grenoble, France), SOLEIL (Saclay, France) and the French CRG committees for the provision of beamtime. 


\section{References}

Alary C. (2001) Technical report Douai - Fr., CNRSSP: 72.

Alary C. and Demougeot-Renard H. (2008) Fate of pollutant load in a small canalised river (Scarpe, North of France): understanding the spatial distribution of heavy metals in sediments using factorial kriging analysis. International Symposium on Sediment Management (I2SM), Lille, France.

Audry S., Blanc G. and Schäfer J. (2005) The impact of sulphide oxidation on dissolved metal (Cd, $\mathrm{Zn}, \mathrm{Cu}, \mathrm{Cr}, \mathrm{Co}, \mathrm{Ni}, \mathrm{U})$ inputs into the Lot-Garonne fluvial system (France). Applied Geochemistry, 20, 919-931.

Baker A.J.M. and Brooks R.R. (1989). Terrestrial higher plants which hyperaccumulate metallic elements - a review of their distribution, ecology and phytochemistry. Biorecovery $\mathbf{1}$, $81-126$.

Barillot C.D.C., Sarde C.O., Bert V., Tarnaud E. and Cochet N. (2013). A standardized method for the sampling of rhizosphere and rhizoplan soil bacteria associated to a herbaceous root system. Annals of Microbiology 63 (2), 471-476

Barrett K.A. and McBride M.B. (2007) Dissolution of zinc-cadmium sulfide solid solutions in aerated aqueous suspension. Soil Science Society of America Journal 71, 322-328.

Bert V., Macnair M.R., De Laguerie P., Saumitou-Laprade P. and Petit D. (2000) Zinc tolerance and accumulation in metallicolous populations of Arabidopsis halleri (Brassicaceae). New Phytologist 146, 225-233.

Bert V., Bonnin I., Saumitou Laprade P., de Laguerie P. and Petit D. (2002) Do Arabidopsis halleri from nonmetallicolous populations accumulate zinc and cadmium more effectively than those from metallicolous populations? New Phytologist, 155, 47-57.

Bert V., Seuntjens P., Dejonghe W., Lacherez S., Thuy H.T.T., Vandecasteele B. (2009) Phytoremediation as a management option for contaminated sediments in tidal marshes, flood 
control areas and dredged sediment landfill sites. Environmental Science and Pollution Research 16: 745-764.

Bert V., Lors C., Ponge J.-F., Caron L., Biaz A., Dazy M. and Masfaraud J.-F. (2012) Metal immobilization and soil amendment efficiency at a contaminated sediment landfill site: A field study focusing on plants, springtails, and bacteria. Environmental Pollution 169, 1-11.

Bolan N.S., Park J.H., Robinson B., Naidu R., and Huh K.Y. (2011) Chapter four Phytostabilization: A Green Approach to Contaminant Containment. Advances in Agronomy, 112, 145-204.

Brown S., Chaney R., Hallfrisch J., Ryan J.A. and Berti W.R. (2004) In situ soil treatments to reduce the phyto- and bioavailability of lead, zinc, and cadmium. Journal of Environmental Quality, 33, 522-531.

Bruno I., Cole J., Edgington P., Kessler M., Macrae C., McCabe P., Pearson J. and Taylor R. (2002) New software for searching the Cambridge Structural Database and visualising crystal structures. Acta Crystallographica B 58, 389-397.

Carroll S. A., O’Day P. A., Esser B. and Randall, S. (2002) Speciation and fate of trace metals in estuarine sediments under reduced and oxidized conditions, Seaplane Lagoon, Alameda Naval Air Station (USA). Geochemical Transactions 3, 81-101.

Cuny D., Denayer F.O., de Foucault B., Schumacker R., Colein P. and Van Haluwyn C. (2004) Patterns of metal soil contamination and changes in terrestrial cryptogamic communities. Environmental Pollution, 129, 289-297.

de Livera J., McLaughlin M.J., Hettiarachchi G.M., Kirby J.K. and Beak, D.G. (2011) Cadmium solubility in paddy soils: Effects of soil oxidation, metal sulfides and competitive ions. Science of the Total Environment, 409 (8), 1489-1497.

Farinati S., DalCorso G., Panigati M. and Furini A. (2011) Interaction between selected bacterial strains and Arabidopsis halleri modulates shoot proteome and cadmium and zinc accumulation. Journal of Experimental Botany, 62, 3433-3447. 
Fulda B., Voegelin A., Ehlert K. and Kretzschmar R. (2013) Redox transformation, solid phase speciation and solution dynamics of copper during soil reduction and reoxidation as affected by sulfate availability. Geochimica et Cosmochimica Acta 123, 385-402.

Gomez-Balderas C.D.C., Cochet N., Bert V., Tarnaud E. and Sarde C.-O. (2014) 16S rDNA analysis of bacterial communities associated with the hyper accumulator Arabidopsis halleri grown on a Zn and Cd polluted soil. European Journal of Soil Biology 60, 16-23.

Hamon, R.E., McLaughlin, M.J., Naidu, R., Correll, R. (1998) Long-term changes in cadmium bioavailability in soil. Environmental Science and Technology 32, 3699-3703.

Hinsinger P. (1998) How do plant roots acquire mineral nutriments? Chemical processes involved in the rhizosphere. Advances in Agronomy, 64, 225-265.

Hinsinger P., Plassard C., Tang C. and Jaillard B. (2003) Origins of root-mediated pH changes in the rhizosphere and their responses to environmental constraints: A review. Plant and Soil, 248, 43-59.

Hinsinger P., Plassard C. and Jaillard B. (2006) Rhizosphere: A new frontier for soil biogeochemistry. Journal of Geochemical Exploration 88, 210-213.

Huguet S., Bert V., Laboudigue A., Barthès V., Isaure M.P., Llorens I., Schat H. and Sarret G. (2012) Cd speciation and localization in the hyperaccumulator Arabidopsis halleri. Environmental and Experimental Botany, 82, 54-65.

Isaure M.P., Laboudigue A., Manceau A., Sarret G., Tiffreau C., Trocellier P., Lamble G., Hazemann J.L. and Chateigner D. (2002) Quantitative Zn speciation in a contaminated dredged sediment by $\mu$-PIXE, $\mu$-SXRF, EXAFS spectroscopy and principal component analysis. Geochimica et Cosmochimica Acta, 66, 1549-1567.

Isaure M.P., Manceau A., Geoffroy N., Laboudigue A., Tamura N. and Marcus M.A. (2005) Zinc mobility and speciation in soil covered by contaminated dredged sediment using 
micrometer-scale and bulk-averaging X-ray fluorescence, absorption and diffraction techniques. Geochimica et Cosmochimica Acta, 69, 1173-1198.

Isaure M.P., Fayard B., Sarret G., Pairis S. and Bourguignon J. (2006) Localization and chemical forms of cadmium in Arabidopsis thaliana. Spectrochimica Acta B, 61, 1242-1252.

Isaure M.P., Huguet S., Meyer, C.L., Castillo-Michel H., Testemale D., Vantelon D., Saumitou-Laprade P., Verbruggen N. and Sarret G. (2015) Evidence of various mechanisms of $\mathrm{Cd}$ sequestration in the hyperaccumulator Arabidopsis halleri, the non-accumulator Arabidopsis lyrata, and their progenies by combined synchrotron-based techniques. Journal of Experimental Botany. 66, 3201-3214.

Karlsson T., Persson P. and Skyllberg U. (2005) Extended X-ray absorption fine structure spectroscopy evidence for the complexation of cadmium by reduced sulfur groups in natural organic matter. Environmental Science and Technology, 39, 3048-3055.

Karlsson T. and Skyllberg U. (2007) Complexation of zinc in organic soils - EXAFS evidence for sulfur associations. Environmental Science and Technology, 41, 119-124.

Li T., Liang C., Han X. and Yang X. (2013) Mobilization of cadmium by dissolved organic matter in the rhizosphere of hyperaccumulator Sedum alfredii. Chemosphere 91, 970-976.

Lions J., Guérin V., Bataillard P., Van der Lee J. and Laboudigue A. (2010) Metal availability in a highly contaminated, dredged-sediment disposal site: Field measurements and geochemical modelling. Environmental Pollution, 158, 2857-2864.

Liu C., Frenkel A.I., Vairavamurthy A. and Huang P.M. (2001) Sorption of cadmium on humic acid: Mechanistic and kinetic studies with atomic force microscopy and X-ray absorption fine structure spectroscopy. Canadian Journal of Soil Science, 81 (3) Special Iss. SI, 337-348.

Lors C., Tiffreau C. and Laboudigue A. (2004) Effects of bacterial activities on the release of heavy metals from contaminated dredged sediments. Chemosphere, 56, 619-630. 
Marschner H. (1995) Mineral nutrition of higher plants, second edition Academic Press, London.

McBride M.B., Barrett K.A. and Martinez C.E. (2006) Zinc and cadmium distribution and leaching in a metalliferous peat. Water Air and Soil Pollution, 171, 67-80.

Meyer C.L., Kostecka A.A., Saumitou-Laprade P., Créach A., Castric V., Pauwels M. and Frérot H. (2010) Variability of zinc tolerance among and within populations of the pseudometallophyte species Arabidopsis halleri and possible role of directional selection. New Phytologist 185, 130-142

Meyer C.L., Juraniec M., Huguet S., Chaves-Rodriguez E., Salis P., Isaure M.P., Goormaghtigh E. and Verbruggen N. (2015). Intraspecific variability of cadmium tolerance and accumulation, and cadmium-induced cell wall modifications in the metal hyperaccumulator Arabidopsis halleri. Journal of Experimental Botany, 66, 3215-3227.

Mishra B., Boyanov M., Bunker B.A., Kelly S.D., Kemner K.M. and Fein J.B. (2010) Highand low-affinity binding sites for $\mathrm{Cd}$ on the bacterial cell walls of Bacillus subtilis and Shewanella oneidensis. Geochimica et Cosmochimica Acta, 74, 4219-4233.

Nolan A.L., Zhang H. and McLaughlin M.J. (2005) Prediction of zinc, cadmium, lead, and copper availability to wheat in contaminated soils using chemical speciation, diffusive gradients in thin films, extraction, and isotopic dilution techniques. Journal of Environmental Quality, 34, 496-507.

O'Day P., Carrol S.A. and Waychunas G.A. (1998) Rock-Water interactions controlling zinc, cadmium, and lead concentrations in surface waters and sediments, US tri-state mining district. 1. Molecular identification using X-ray absorption spectroscopy. Environmental Science and Technology, 32, 943-955.

Panfili F., Manceau A., Sarret G., Spadini L., Kirpichtchikova T., Bert V., Laboudigue A., Marcus M., Ahamdach N. and Libert M. (2005) The effect of phytostabilization on Zn speciation in a dredged contaminated sediment using scanning electron microscopy, X-ray 
fluorescence, EXAFS spectroscopy and principal components analysis. Geochimica et Cosmochimica Acta, 69, 2265-2284.

Pauwels M., Frérot H., Bonnin I. and Saumitou-Laprade P. (2006) A broad-scale analysis of population differentiation for $\mathrm{Zn}$ tolerance in an emerging model species for tolerance study: Arabidopsis halleri (Brassicaceae). Journal of Evolutionary Biology, 19, 1838-1850.

Piou S., Bataillard P., Laboudigue A., Férard J.F. and Masfaraud J.F. (2009) Changes in the geochemistry and ecotoxicity of a $\mathrm{Zn}$ and $\mathrm{Cd}$ contaminated dredged sediment over time after land disposal. Environmental Research, 109, 712-720.

Proux O., Nassif V., Prat A., Ulrich O., Lahera E., Biquard X., Menthonnex J.J. and Hazemann, J.L. (2006). Feedback system of a liquid-nitrogen-cooled double-crystal monochromator: design and performances. Journal of Synchrotron Radiation 13, 59-69.

Ravel B. (2009). ATHENA Users' Guide, version 1.5

http://cars9.uchicago.edu/ ravel/software/doc/Athena/html/athena.pdf

Ravel B. and Newville M. (2005). ATHENA and ARTEMIS: interactive graphical data analysis using IFEFFIT. Journal of Synchrotron Radiation, 12, 537-541.

Roosens N., Willems G. and Saumitou-Laprade P. (2008) Using Arabidopsis to explore zinc tolerance and hyperaccumulation. Trends in Plant Science 13, 208-215.

Sajidu S.M.I., Masamba W.R.L., Thole B. and Mwatseteza J.F. (2008) Groundwater fluoride levels in villages of Southern Malawi and removal studies using bauxite, International Journal of Physical Sciences, 3, pp. 001-011.

Sarret G., Connan J., Kasrai M., Eybert-Bérard L., Bancroft G.M. (1999). Characterization of sulfur in asphaltenes by sulfur K- and L-edge XANES spectroscopy. Journal of Synchrotron Radiation, 6, 670-672.

Sarret G., Balesdent J., Bouziri L., Garnier J.M., Marcus M.A., Geoffroy N., Panfili F. and Manceau A. (2004) Zn speciation in the organic horizon of a contaminated soil by micro X- 
ray fluorescence, micro and powder EXAFS spectroscopy and isotopic dilution. Environmental Science and Technology, 38, 2792-2801.

Sarret G., Willems G., Isaure MP., Marcus M.A., Fakra S., Frérot H., Pairis S., Geoffroy N., Manceau A. and Saumitou-Laprade P. (2009) Zn distribution and speciation in Arabidopsis halleri $\mathrm{x}$ Arabidopsis lyrata progenies presenting various $\mathrm{Zn}$ accumulation capacities. New Phytologist, 184, 581-595.

Szymanski J.T. (1978) The crystal structure of cernýite, Cu2CdSnS4, a cadmium analogue of stannite. The Canadian Mineralogist, 16, 147-151

Thiry M., Huet-Taillanter S. and Schmitt J.M. (2002) The industrial waste land of Mortagnedu-Nord (59) - I - Assesment, composition of the slags, hydrochemistry, hydrology and estimate of the outfluxes. Bulletin De La Societe Geologique De France, 173, 369-381.

Tsednee M., Yang S.-C., Lee D.-C., Yeh K.-C. (2014) Root-secreted nicotianamine from Arabidopsis halleri facilitates zinc hypertolerance by regulating zinc bioavailability. Plant Physiology, 166, 839-852.

Vansimaeys C., Alary C., Bataillard P., Zentar R. and Laboudigue A. (2009) Ripening of contaminated sediments: effect on organic matter-bound and iron oxides-bound metals. International Conference on the Biogeochemistry of Trace Element (ICOBTE), Chihuahua, Mexico.

Verbruggen N., Juraniec M., Baliardini C. and Meyer C.-L. (2013) Tolerance to cadmium in plants: the special case of hyperaccumulators. Biometals 26, 633-638.

Wenzel W.W. and Jockwer F. (1999) Accumulation of heavy metals in plants grown on mineralised soils of the Austrian Alps. Environmental Pollution, 104, 145-155.

Wenzel W.W., Bunkowski M., Puschenreiter M. And Horak O. (2003) Rhizosphere characteristics of indigenously growing nickel hyperaccumulator and excluder plants on serpentine soil. Environmental Pollution, 123, 131-138. 
Wenzel W.W. (2009) Rhizosphere processes and management in plant-assisted bioremediation (phytoremediation) of soils. Plant and Soil, 321, 385-408.

Zhang H., Zhao F.J., Sun B., Davison W. and McGrath S.P. (2001) A new method to measure effective soil solution concentration predicts copper availability to plants. Environmental Science and Technology, 35, 2602-2607. 


\section{Table captions}

Table 1: General properties of studied sediment. Averages and standard deviations over 3 samples.

Table 2: First shell structural parameters by shell fittings of the EXAFS spectra for sediment samples before and after culture, with or without plant, and for references.

\section{Figure captions}

Figure 1: Schema summarizing the design of culture experiment. $t i$ means « initial time » that corresponds to the time of $A$. halleri seedlings transfer in sediment. The monitoring was done every month from the time $t_{0}$.

Figure 2: Cd K-edge EXAFS spectra for reference compounds including $\mathrm{CdCO}_{3}$ (powder); $\mathrm{Cd}(\mathrm{OH})_{2}$ (powder); $\mathrm{CdCl}_{2}$ (powder); $\mathrm{CdSO}_{4}$ (powder); Cd-goethite : 0.8\% Cd (powder); Cdphosphate : $\mathrm{Cd}_{5} \mathrm{H}_{2}\left(\mathrm{PO}_{4}\right)_{4} \cdot 4 \mathrm{H}_{2} \mathrm{O}$ (powder); $\mathrm{Cd}\left(\mathrm{NO}_{3}\right)_{2}$ (powder); $\mathrm{Cd}^{2+}: 10 \mathrm{mM} \mathrm{Cd}^{2+}$ at $\mathrm{pH}=2.2$ (Cd dissolved form); Cd-cellulose : described in Isaure et al., 2006; Cd-OAs : 5 mM Cd, 14 $\mathrm{mM}$ citrate, $100 \mathrm{mM}$ malate and $400 \mathrm{mM}$ succinate at pH 5.5; Cd-cysteine : ( $\mathrm{Zn}, \mathrm{Cd}, \mathrm{Fe}) \mathrm{S}$ as mixed sulfide (powder) characterized by XRD; CdS (powder).

Figure 3: (A) Cd K-edge EXAFS spectra for sediment before and after culture, with or without plant. Each spectrum (plain lines) is shown with its linear combination fit (dotted lines). (B) Distribution of $\mathrm{Cd}$ species for samples after normalization of the percentage to $100 \%$.

Figure 4: Cd K-edge EXAFS spectra (A) and Fourier transforms (B) for sediment before and after culture, with or without plant, and for references: $\mathrm{CdCO}_{3}$ and $\mathrm{Cd}$-phosphate as representative of $\mathrm{Cd}-\mathrm{O}$ bonds and $\mathrm{CdS}$ and $(\mathrm{Zn}, \mathrm{Cd}, \mathrm{Fe}) \mathrm{S}$ as representative of $\mathrm{Cd}-\mathrm{S}$ ligands. Each spectrum (plain lines) is shown with their shell fittings (dotted lines).

Figure 5: SEM EDS images and EDS spectrum recorded in Cd-rich spot of a coarse fraction grain of sediment before culture (A) and elemental maps for $\mathrm{Cd}, \mathrm{S}$ and $\mathrm{P}$ of this region 
recorded by $\mu \mathrm{XRF}$ (B), with a step-size of $3 \mu \mathrm{m}$ and 1s/pixel of counting time. Spots were called "P1-before culture" and "P2-before culture".

Figure 6: Light microscope and SEM EDS images of a coarse grain of sediment after culture with MET plant and EDS spectrum recorded in Cd-rich spot (A), and elemental maps for Cd, $\mathrm{S}, \mathrm{P}, \mathrm{Si}$ and $\mathrm{Al}$ of this region recorded by $\mu \mathrm{XRF}(\mathrm{B})$, with a step-size of $3 \mu \mathrm{m}$ and $1 \mathrm{~s} /$ pixel of counting time. Spots were called "P3A-after culture", "P3B-after culture" and "P3C-after culture". Another Cd-rich grain was investigated: elemental maps for Cd, S, P, Si and Al of this other region recorded by $\mu \mathrm{XRF}(\mathrm{C})$, with a step-size of $3 \mu \mathrm{m}$ and $1 \mathrm{~s} /$ pixel of counting time. Spot was called "P4-after culture".

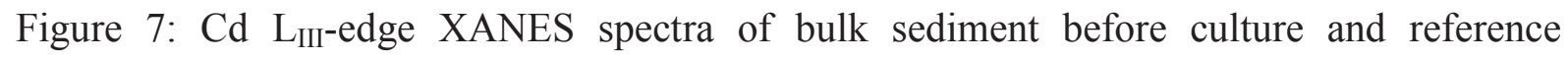
compounds (XANES spectra) and $\mu$ XANES spectra recorded on Cd-rich spots of sediment before culture and after culture with MET plant. Experimental spectra are in plain lines and best linear combination fits are in dotted lines. Reference compounds representative of $\mathrm{Cd}-\mathrm{O}$ ligands are $\mathrm{CdCO}_{3}, \mathrm{Cd}$-organic acid (Cd-malate), and representative references of $\mathrm{Cd}-\mathrm{S}$ ligands are Cd-thiol (Cd-cysteine), and sulfides: $\mathrm{CdS}$ and ( $\mathrm{Zn}, \mathrm{Cd}, \mathrm{Fe}) \mathrm{S}$.

Figure 8: S K-edge XANES spectra of bulk sediment before culture and reference compounds (XANES spectra) and $\mu$ XANES spectra recorded on Cd-rich spots of sediment before culture and after culture with MET plant. Experimental spectra are in plain lines and best linear combination fits are in dotted lines. Reference compounds are oxided sulfur (Cd-sulfate), sulfoxide (DL-methionine sulfoxide, from Sarret et al., 1999), organic sulfide (DL-cysteine, from Sarret et al., 1999) and mineral sulfides (CdS and (Zn, Cd, Fe)S ).

Figure 9: Distribution of $\mathrm{Cd}(\mathrm{A})$ and $\mathrm{S}$ (B) species for samples after normalization of the percentage to $100 \%$. Percentages presented are the average over satisfactory fits, defined by NSS comprised between the value obtained for the best fit $\left(\mathrm{NSS}_{\text {best }}\right)$ and $1.1 \mathrm{NSS}_{\text {best }}$.

Figure 10: Comparison between concentrations of $\mathrm{Cd}$ extractable measured by $\mathrm{Ca}\left(\mathrm{NO}_{3}\right)_{2}$ extraction (A) and Cd phytoavailability estimated by DGT (B), in the sediment cultivated with MET and N-MET plants (grey and white respectively), and in the control (without plant - hatched). All data are averages \pm SD over 3 samples. "PA" means "plant adaptation". On each graph, results of statistical tests are indicated by Latin and Greek letters for MET plant 
culture and N-Met plant culture respectively. A different letter indicates a significant difference at the $P=0.05$ level.

Figure 11: (A) Cd concentrations [mg.L-1] measured in leachates collected from cultivated pots with MET plant (grey) and N-MET plant (white) origins and non cultivated pot as a control (hatched), (B) biomass and (C) Cd concentrations measured in aerial parts of $A$. halleri from MET and N-MET origins. Averages and standard deviations are over 3 samples. For each graph, results of statistical tests are indicated by Greek and Latin letters for pots with MET plant and N-MET plant respectively. A different number or letter indicates a significant difference at the $P=0.05$ level. There is no significant difference of $\mathrm{Cd}$ concentration in leachates measured in control pots without plant. 
Table 1

\begin{tabular}{|c|c|c|c|c|c|}
\hline Clay $<2 \mu \mathrm{m}$ & $\%$ & 18 & \pm & 0.5 & (3) \\
\hline Silt $\quad 2 \mu \mathrm{m}-50 \mu \mathrm{m}$ & $\%$ & 45 & \pm & 1 & (3) \\
\hline Sand $50 \mu \mathrm{m}-2 \mathrm{~mm}$ & $\%$ & 36 & \pm & 1 & (3) \\
\hline $\mathrm{CaCO}_{3}$ (total) & $\%$ & 7.2 & \pm & 0.2 & (3) \\
\hline TOC & $\%$ & 10.5 & \pm & 0.2 & (3) \\
\hline $\mathrm{pH}, \mathrm{H}_{2} \mathrm{O}$ & & 7.48 & + & 0.01 & (3) \\
\hline OM & $\mathrm{g} \mathrm{kg}^{-1}$ & 225 & & 1.3 & (3) \\
\hline CEC Metson & $\mathrm{cmol}(+) \mathrm{kg}^{-1}$ & 25.4 & 1 & 0.5 & (3) \\
\hline $\mathrm{K}\left(\mathrm{K}_{2} \mathrm{O}\right)$ exchangeable & $\mathrm{g} \mathrm{kg}^{-1}$ & 0.24 & & 0.02 & (3) \\
\hline $\mathrm{Mg}(\mathrm{MgO})$ exchangeable & $\mathrm{g} \mathrm{kg}^{-1}$ & 0.599 & & 0.003 & (3) \\
\hline $\mathrm{Ca}(\mathrm{CaO})$ exchangeable & $\mathrm{g} \mathrm{kg}^{-1}$ & 15.47 & - & 0.06 & (3) \\
\hline $\mathrm{Na}\left(\mathrm{Na}_{2} \mathrm{O}\right)$ exchangeable & $\mathrm{g} \mathrm{kg}^{-1}$ & 0.205 & & 0.003 & (3) \\
\hline $\mathrm{P}\left(\mathrm{P}_{2} \mathrm{O}_{5}\right)$ Olsen & $\mathrm{g} \mathrm{kg}^{-1}$ & 0.227 & 1 & 0.003 & (3) \\
\hline Cd concentration & $\mathrm{mg} \mathrm{kg}^{-1}$ & 141 & 1 & 24 & (3) \\
\hline Zn concentration & $\mathrm{mg} \mathrm{kg}^{-1}$ & 4074 & \pm & 280 & (3) \\
\hline Cu concentration & $\mathrm{mg} \mathrm{kg}^{-1}$ & 233 & \pm & 9 & (3) \\
\hline $\mathrm{Pb}$ concentration & $\mathrm{mg} \mathrm{kg}^{-1}$ & 600 & \pm & 20 & (3) \\
\hline Ni concentration & $\mathrm{mg} \mathrm{kg}^{-1}$ & 48 & \pm & 2 & (3) \\
\hline As concentration & $\mathrm{mg} \mathrm{kg}^{-1}$ & 57 & \pm & 4 & (3) \\
\hline
\end{tabular}


Table 2

\begin{tabular}{|c|c|c|c|c|c|c|c|}
\hline References and Samples & K range $\left(\AA^{-1}\right)$ & $\mathrm{R}$ range $(\AA)$ & Atom & $\mathrm{N}$ & $\mathrm{R}(\AA)$ & $\sigma^{2}\left(\AA^{2}\right)$ & NSS \\
\hline \multirow[t]{4}{*}{$\mathrm{CdCO}_{3}$} & {$[3.2-14.7]$} & {$[1.35-4.1]$} & 0 & 6.2 & 2.28 & 0.004 & \multirow{4}{*}{0.0090} \\
\hline & & & C & 6.1 & 3.18 & 0.005 & \\
\hline & & & O & 5.8 & 3.40 & 0.005 & \\
\hline & & & $\mathrm{Cd}$ & 6,0 & 3.93 & 0.004 & \\
\hline \multirow[t]{3}{*}{ Cd-phosphate } & {$[3.2-14.3]$} & {$[0.88-4.5]$} & 0 & 6.1 & 2.27 & 0.008 & \multirow{3}{*}{0.0110} \\
\hline & & & $P$ & 2.9 & 3.44 & 0.009 & \\
\hline & & & $\mathrm{Cd}$ & 1.7 & 3.50 & 0.009 & \\
\hline \multirow[t]{2}{*}{ CdS } & {$[3.5-13.9]$} & {$[1.37-4.7]$} & $s$ & 4,0 & 2.52 & 0.003 & \multirow{2}{*}{0.0150} \\
\hline & & & $\mathrm{Cd}$ & 10.4 & 4.14 & 0.007 & \\
\hline \multirow{4}{*}{$\begin{array}{l}\text { (Zn. Cd. Fe)S } \\
\text { mixed sulfide }\end{array}$} & {$[3.6$ - 13.4] } & {$[1.32-4.6]$} & $\mathrm{s}$ & 4,0 & 2.52 & 0.004 & \multirow{4}{*}{0.0190} \\
\hline & & & $\mathrm{Fe}$ & 0.4 & 3.69 & 0.009 & \\
\hline & & & $\mathrm{Zn}$ & 5,0 & 3.89 & 0.009 & \\
\hline & & & $\mathrm{Cd}$ & 2.5 & 4.18 & 0.009 & \\
\hline \multirow{4}{*}{$\begin{array}{c}\text { Sediment - before culture } \\
\text { Adjustment with }(\mathrm{Zn}, \mathrm{Cd}, \mathrm{Fe}) \mathrm{S} \\
\text { structure }\end{array}$} & {$[3.6-13.4]$} & {$[1.35-4.3]$} & $s$ & 4,0 & 2.51 & 0.004 & \multirow{4}{*}{0.0024} \\
\hline & & & $\mathrm{Fe}$ & 0.3 & 3.69 & 0.009 & \\
\hline & & & $\mathrm{Zn}$ & 4.8 & 3.89 & 0.009 & \\
\hline & & & $\mathrm{Cd}$ & 2.2 & 4.17 & 0.009 & \\
\hline \multirow{2}{*}{$\begin{array}{l}\text { Sediment - before culture } \\
\text { Adjustment with }(\mathrm{Zn}, \mathrm{Cd}, \mathrm{Fe}) \mathrm{S}\end{array}$} & {$[3.6-13.4]$} & {$[1.35-4.3]$} & $s$ & 4.2 & 2.51 & 0.004 & \multirow{3}{*}{0.0037} \\
\hline & & & $\mathrm{Zn}$ & 4.3 & 3.89 & 0.009 & \\
\hline Structure without $\mathrm{Fe}$ atoms & & & $\mathrm{Cd}$ & 3.1 & 4.17 & 0.009 & \\
\hline \multirow{2}{*}{$\begin{array}{l}\text { Sediment without plant } \\
\text { after culture }\end{array}$} & {$[3.2-10.8]$} & {$[1.2-2.9]$} & $\mathrm{O}$ & 5.5 & 2.29 & 0.010 & \multirow{2}{*}{0.0026} \\
\hline & & & s & 0.6 & 2.47 & 0.010 & \\
\hline $\begin{array}{l}\text { Sediment with MET plant } \\
\text { after culture }\end{array}$ & {$[3.2-10.8]$} & [1.2- 2.3] & $\mathrm{O}$ & 6.7 & 2.29 & 0.009 & 0.0039 \\
\hline $\begin{array}{l}\text { Sediment with N-MET plant } \\
\text { after culture }\end{array}$ & {$[3.2-10.8]$} & {$[1.2-2.3]$} & $\mathrm{O}$ & 6.2 & 2.30 & 0.009 & 0.0057 \\
\hline
\end{tabular}

$\mathrm{N}$ : number of atoms, R: interatomic distance, $\sigma 2$ : Debye Waller factor, NSS: residual between fit and experiment. Experimental errors on $N$ and $R$ are $\pm 10 \%$ and $0.01 \AA$ as estimated from the fit of reference compounds. 
Click here to download Figure: s-huguet_STotEn_figures.doc

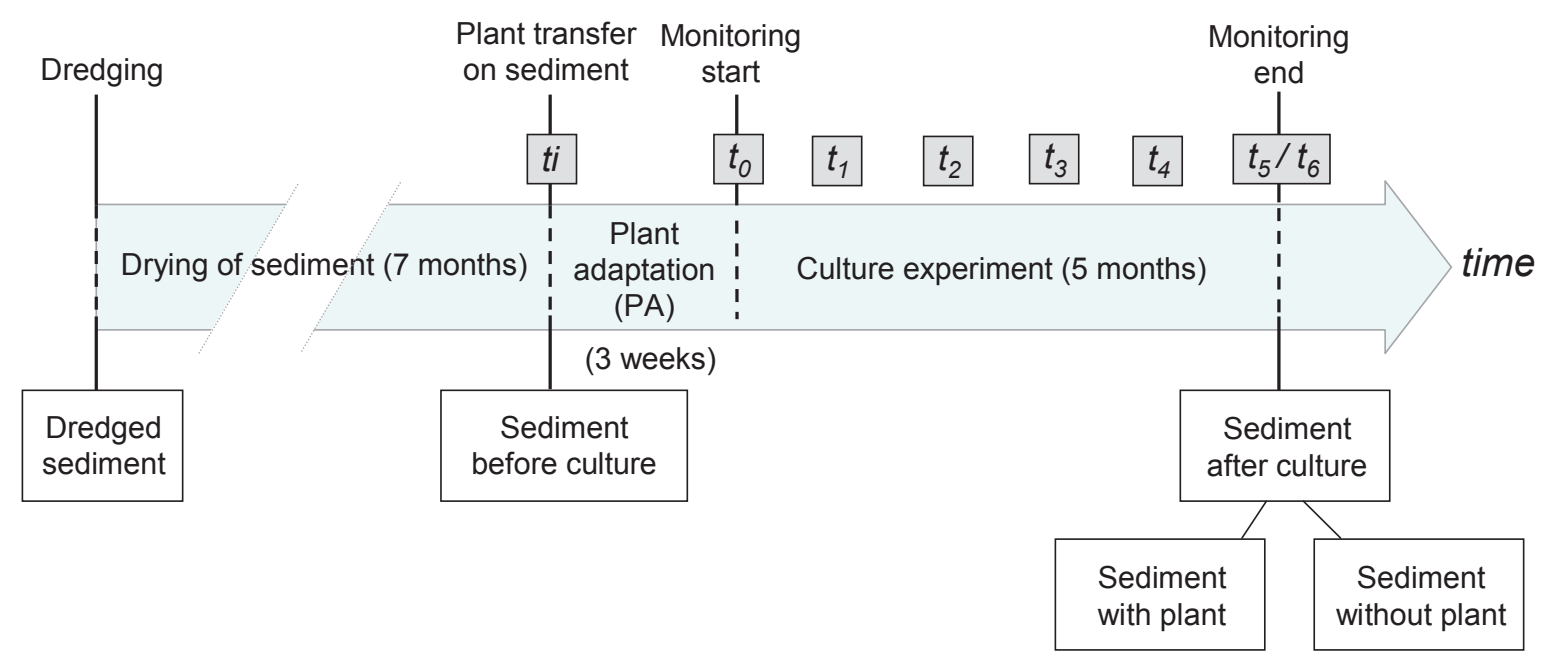

Figure 1. 


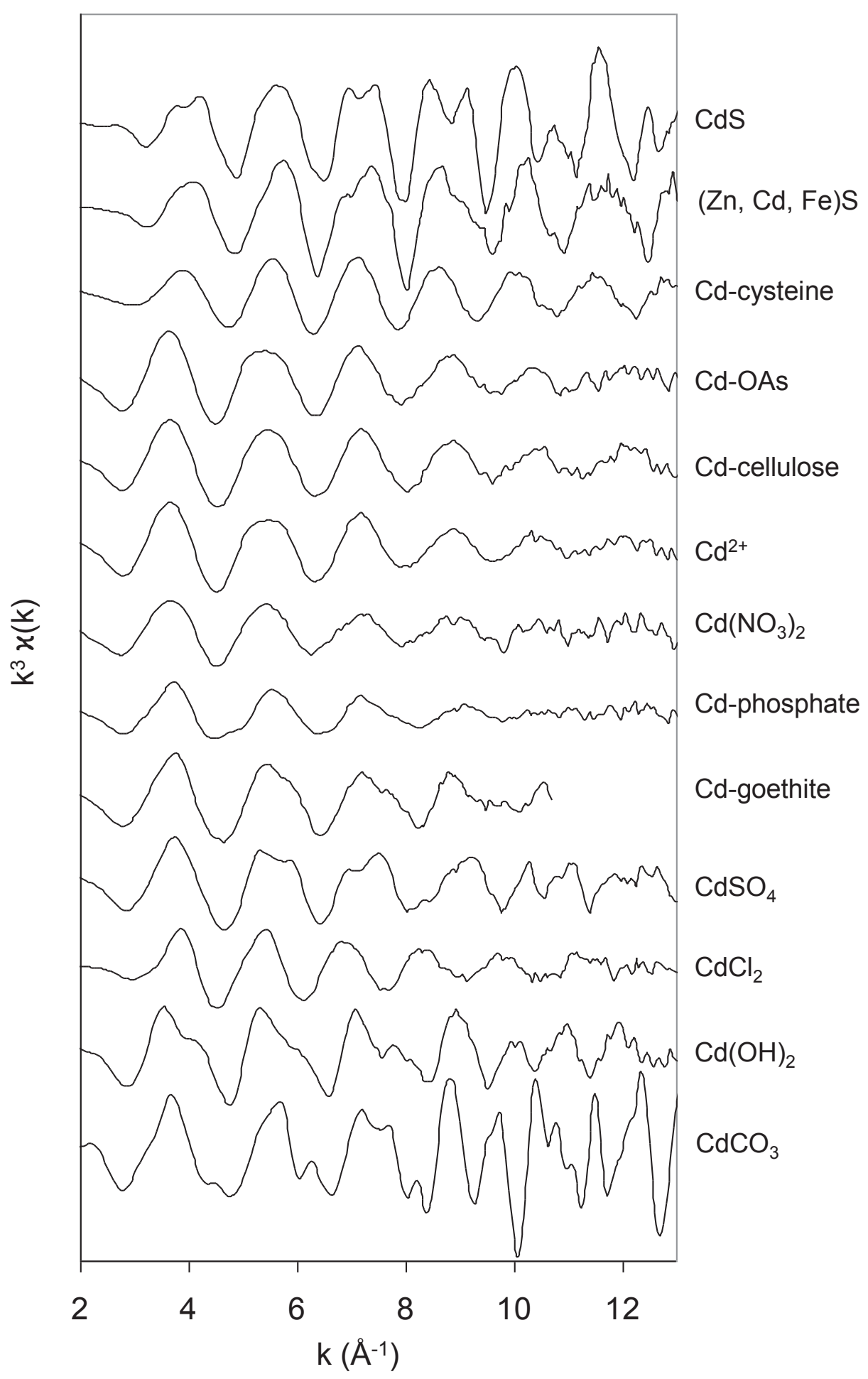

Figure 2. 

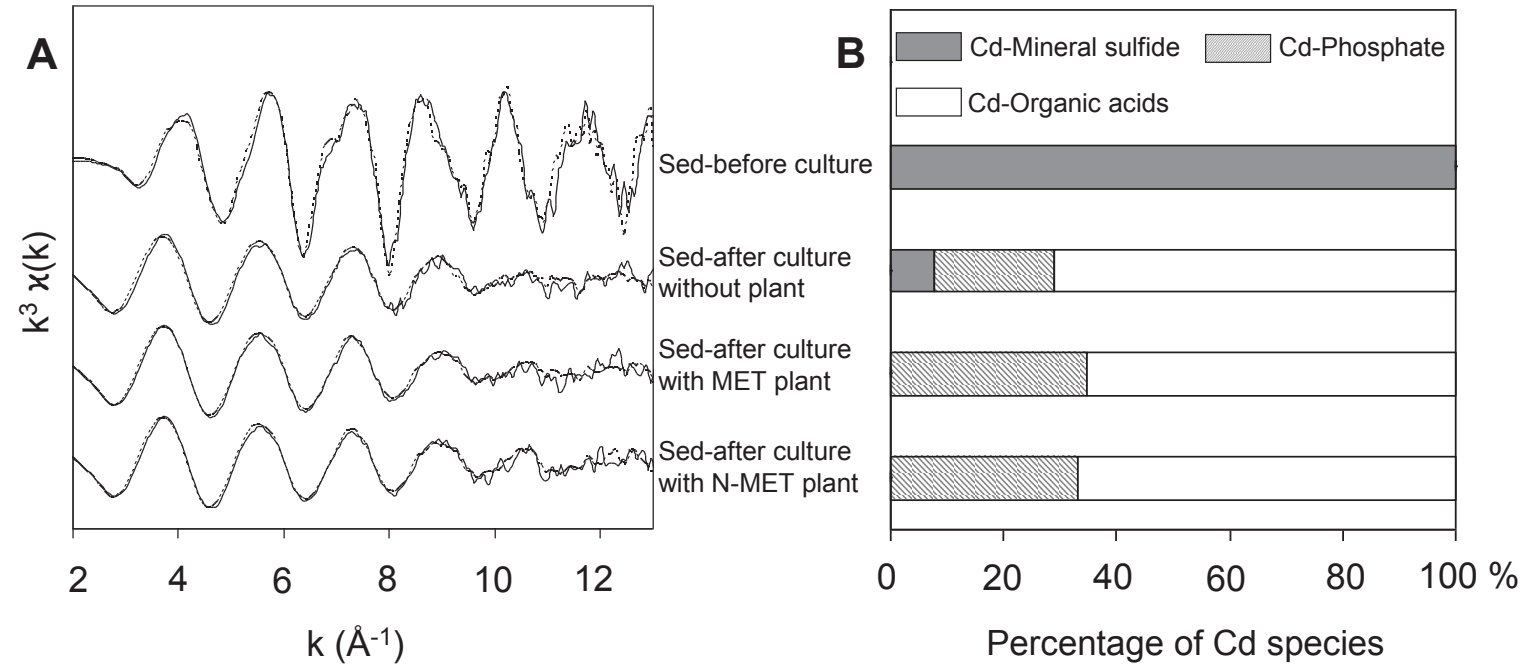

Figure 3. 

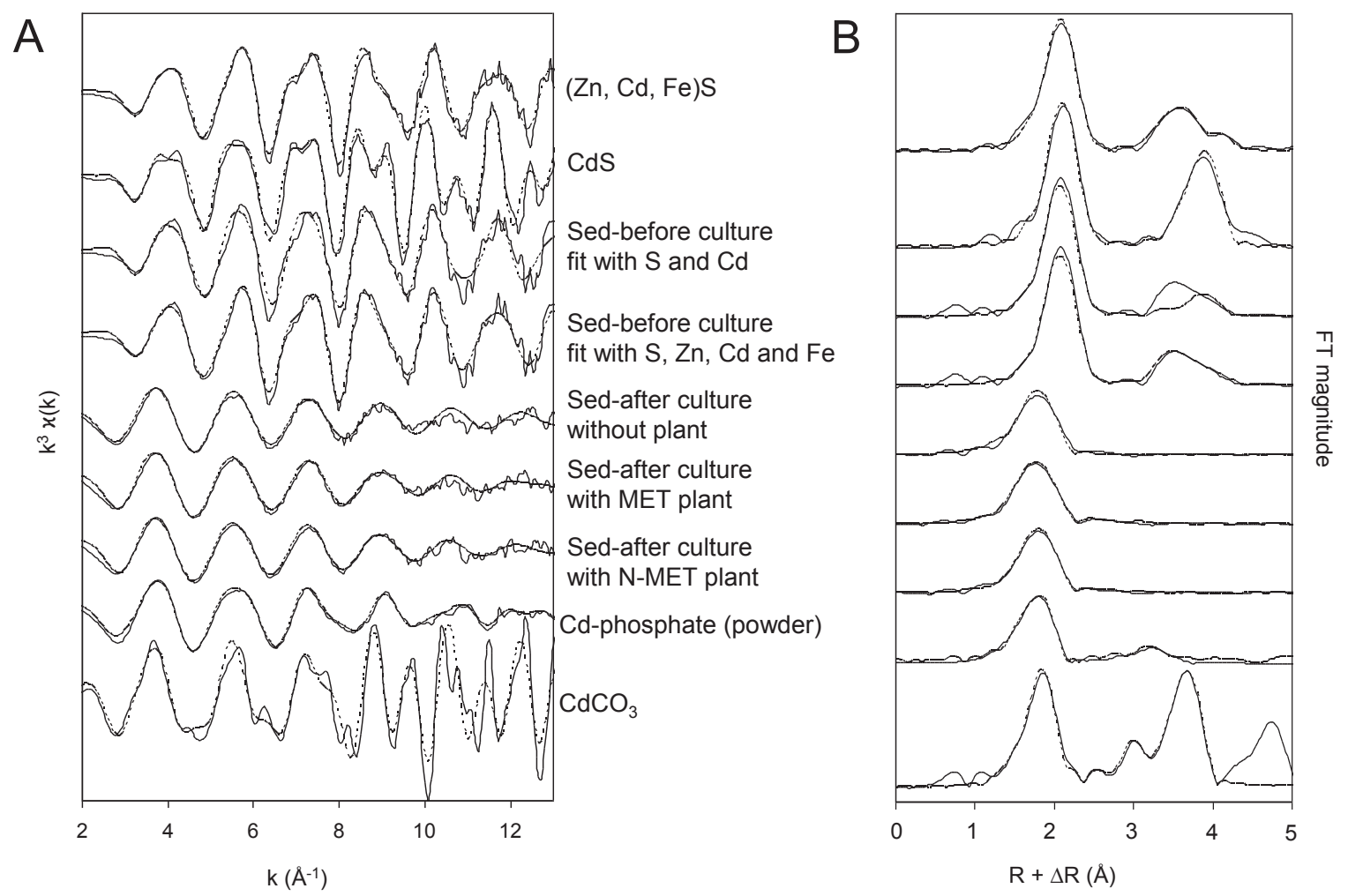

Figure 4. 

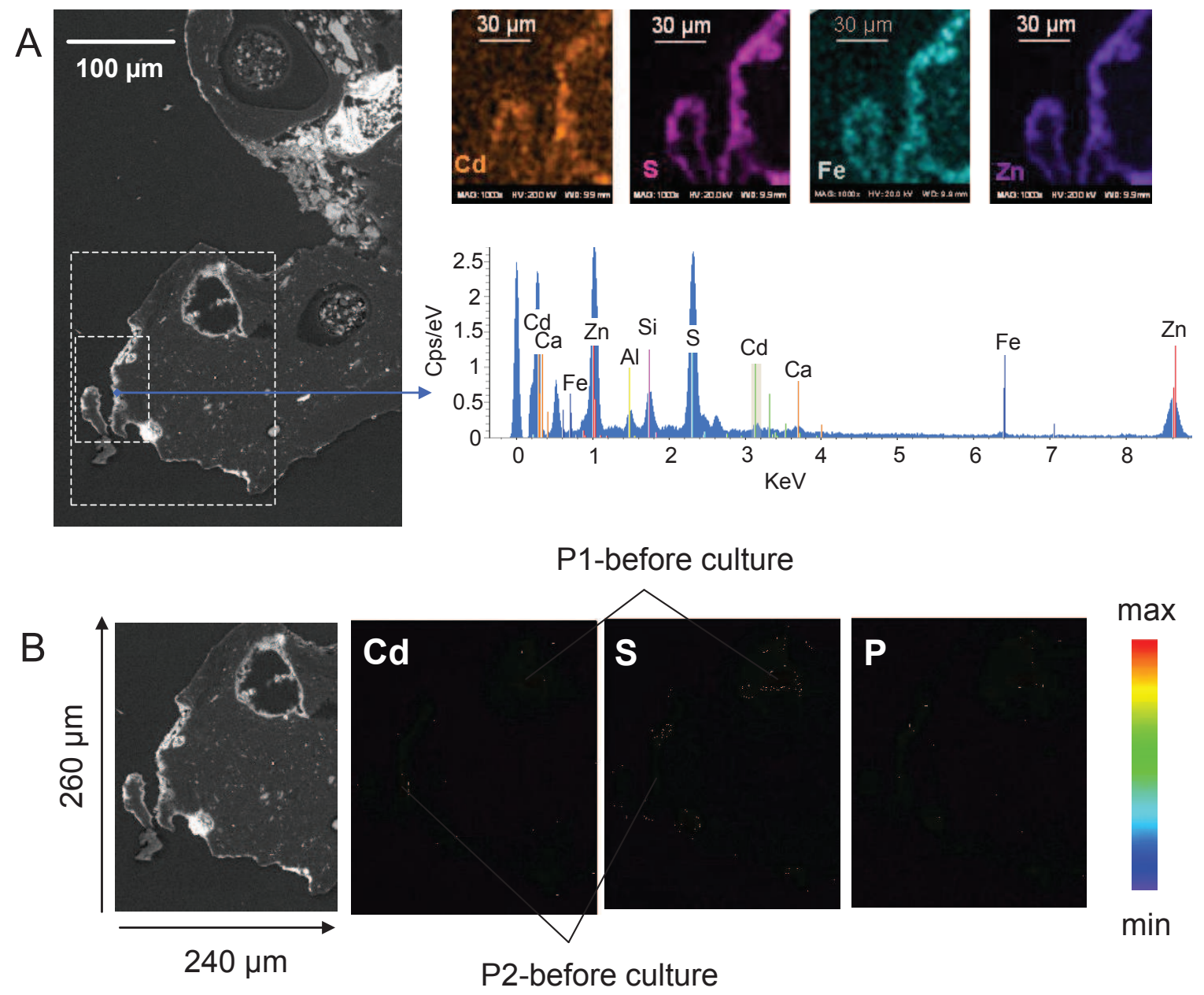

Figure 5. 

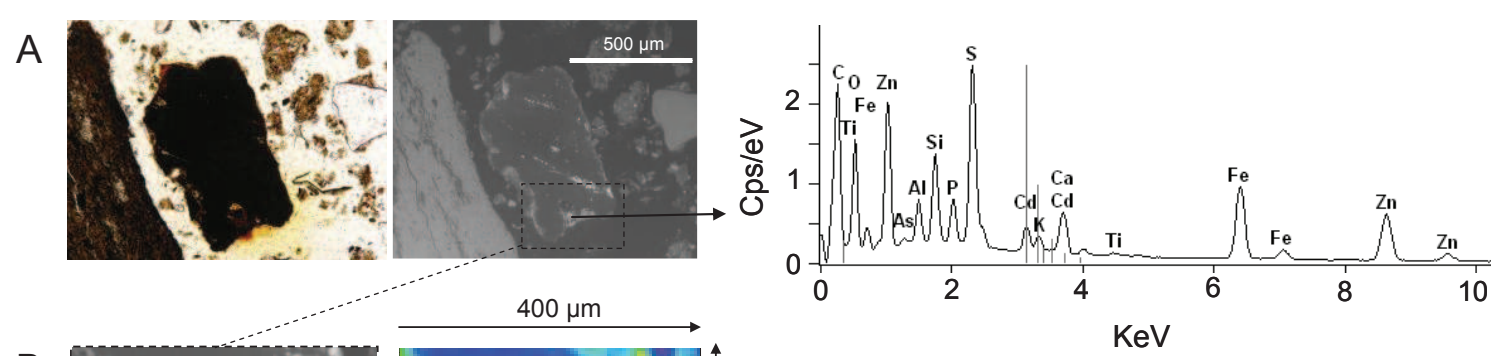

B
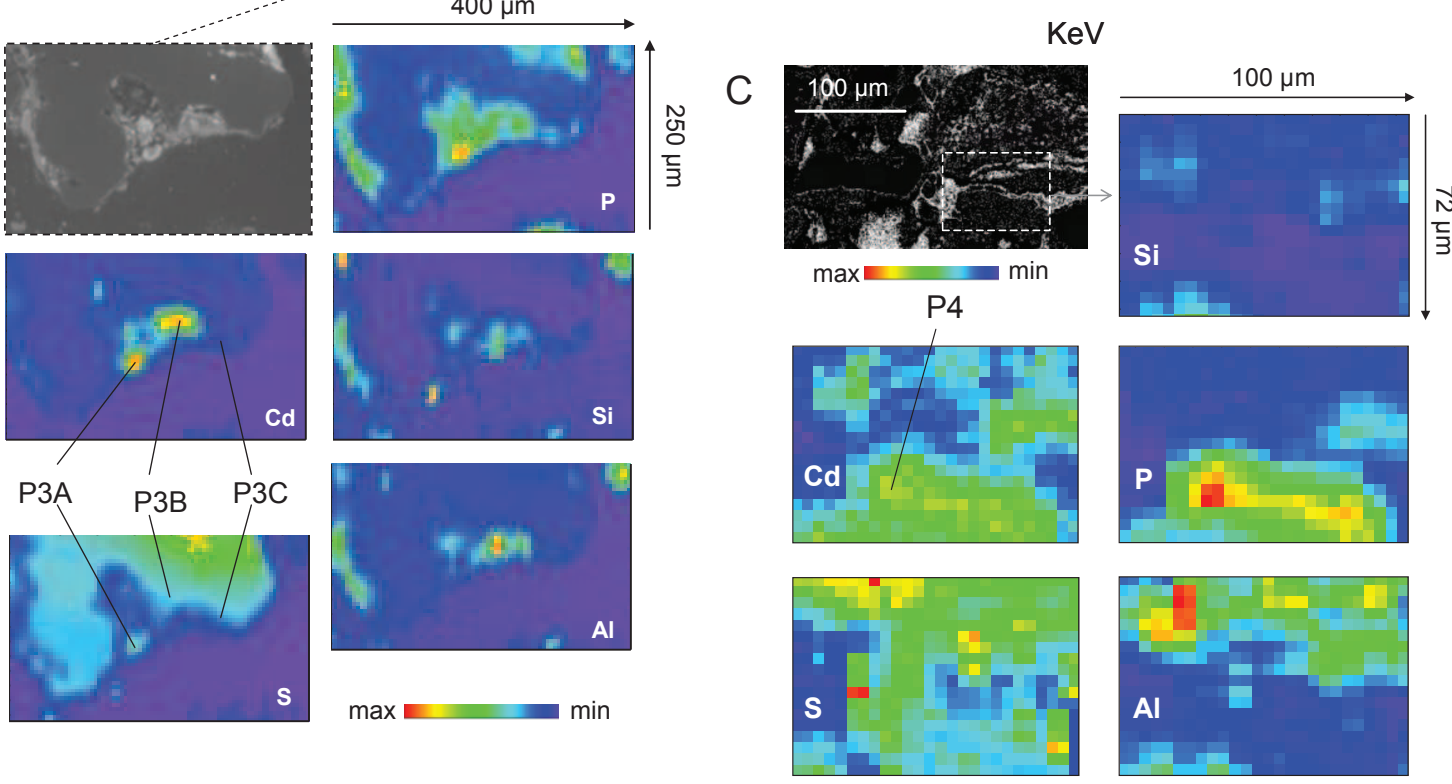

Figure 6. 


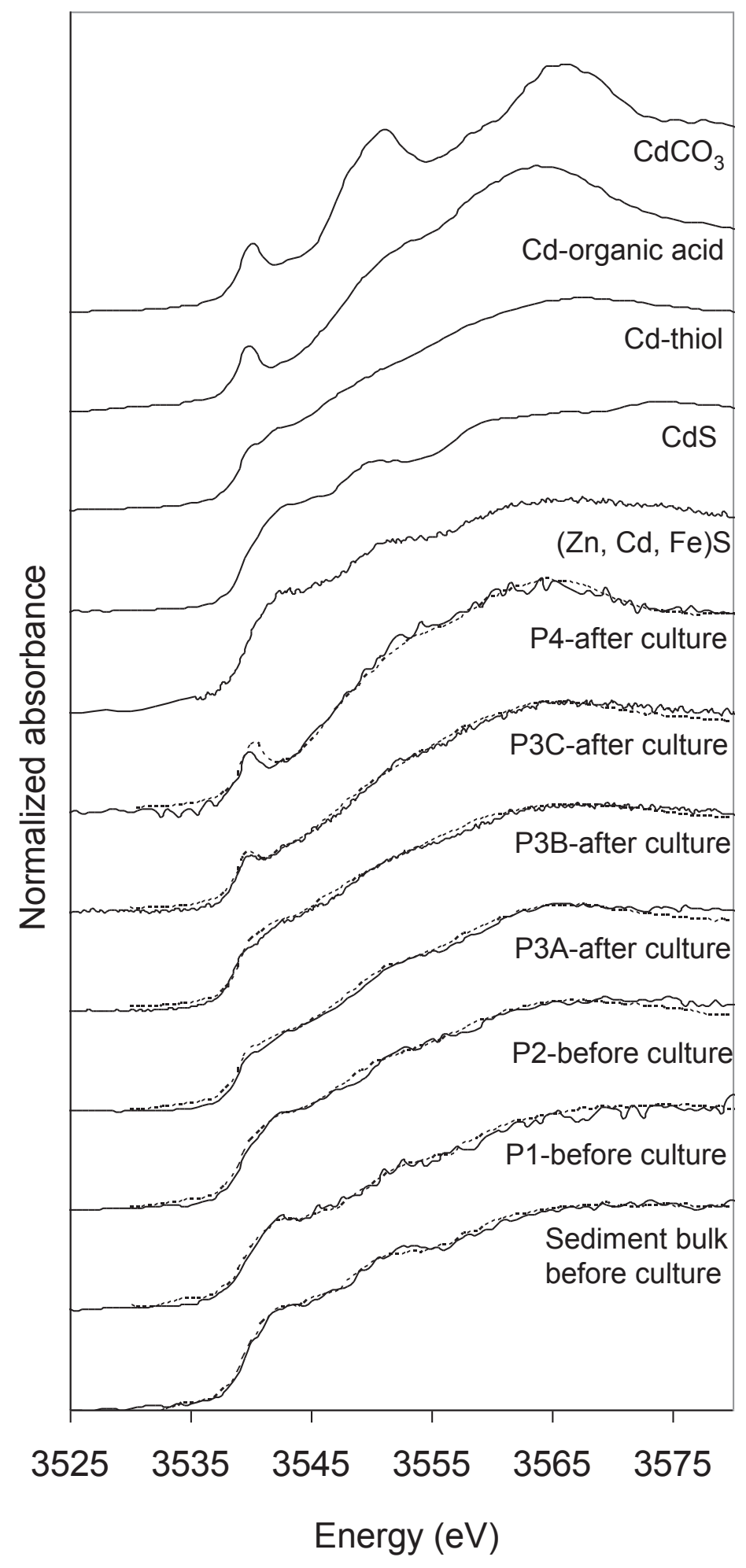

Figure 7. 


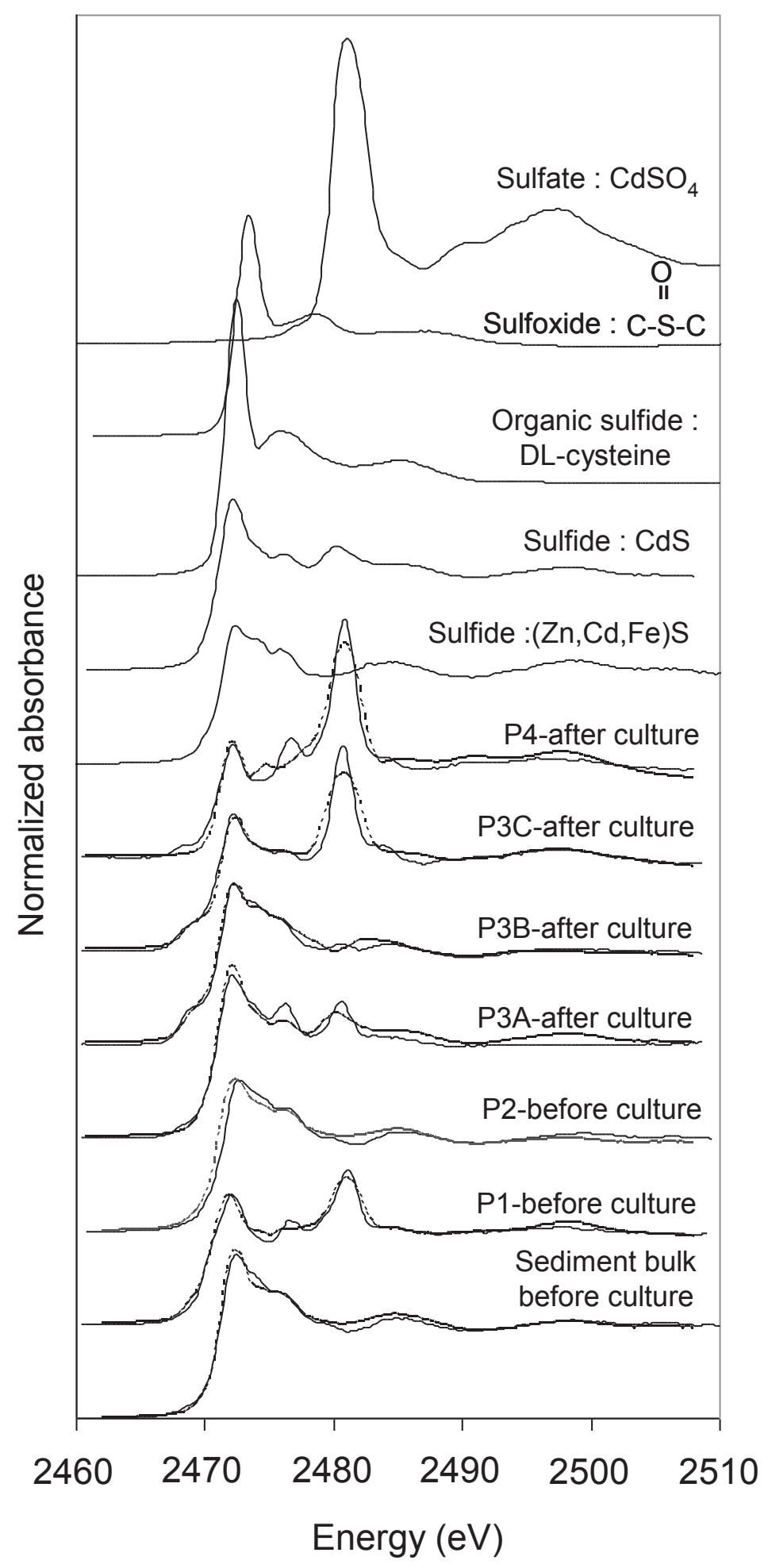

Figure 8. 
A $\quad$ Cd species ( $\mathrm{Cd} \mathrm{L}_{\mathrm{III}^{-}}$-edge $)$

Cd-Mineral sulfide Cd-phosphate

Cd-Organic sulfide $\square$ Cd-Organic acid

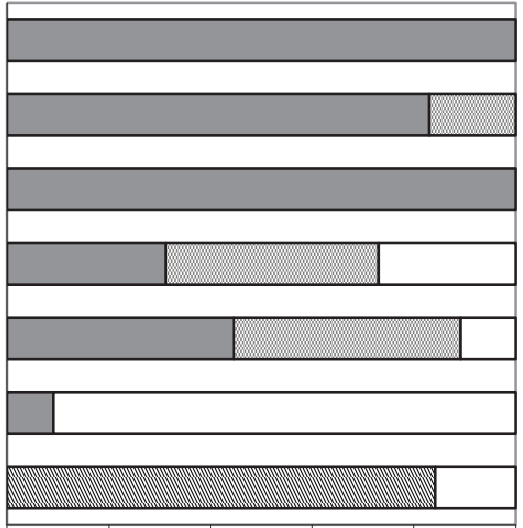

$\begin{array}{llllll}0 \% & 20 \% & 40 \% & 60 \% & 80 \% & 100 \%\end{array}$

Percentage of $\mathrm{Cd}$ species
B S species (S K-edge)

$\square$ Mineral sulfide $\square$ Organic sulfide

$\square$ Oxidized sulfur

Sediment bulk before culture

P1-before culture

P2-before culture

P3A-after culture

P3B-after culture

P3C-after culture

P4-after culture

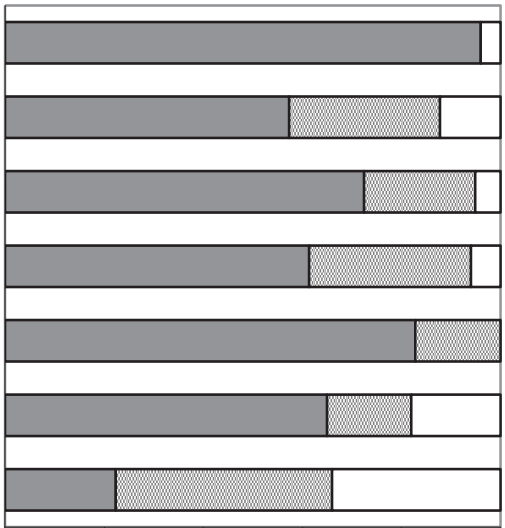

$\begin{array}{llllll}0 \% & 20 \% & 40 \% & 60 \% & 80 \% & 100 \%\end{array}$

Percentage of $\mathrm{S}$ species

Figure 9. 
Without plant $\square$ With MET plant $\square$ With N-MET plant

A

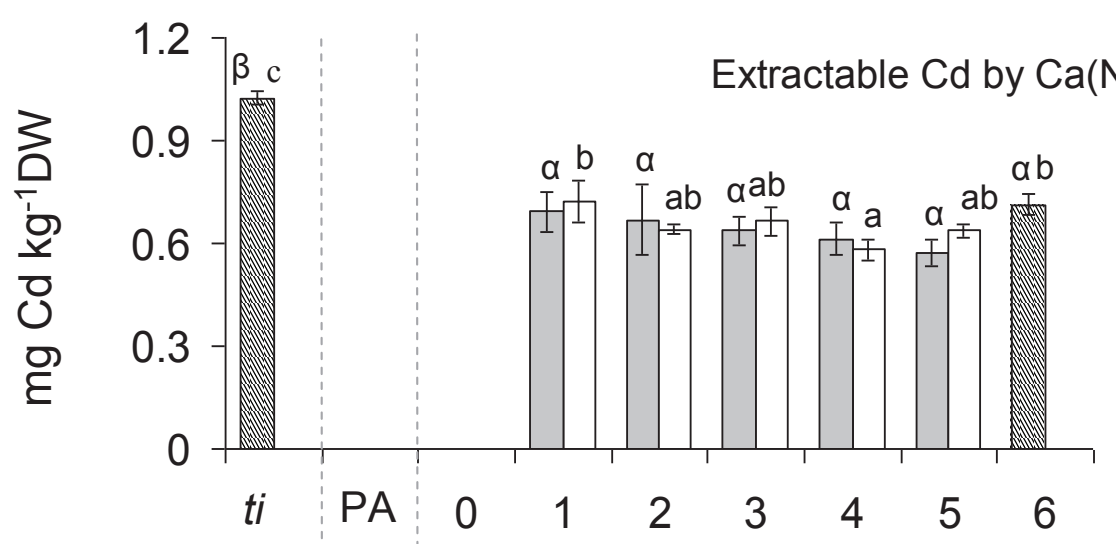

B

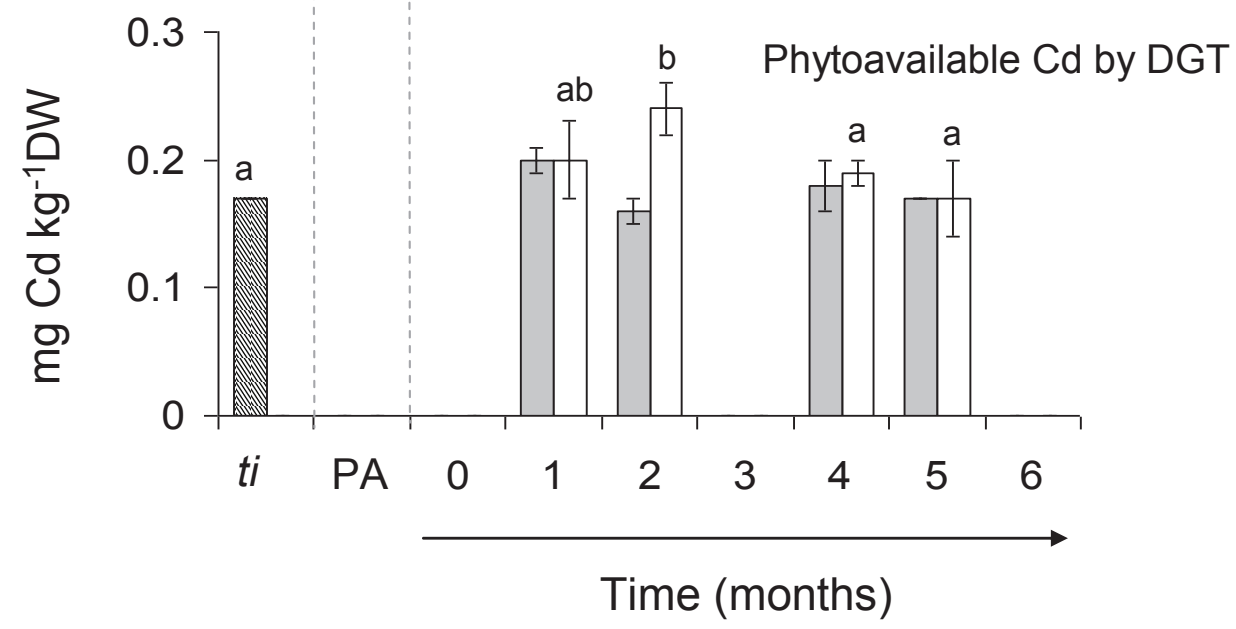

Figure 10. 


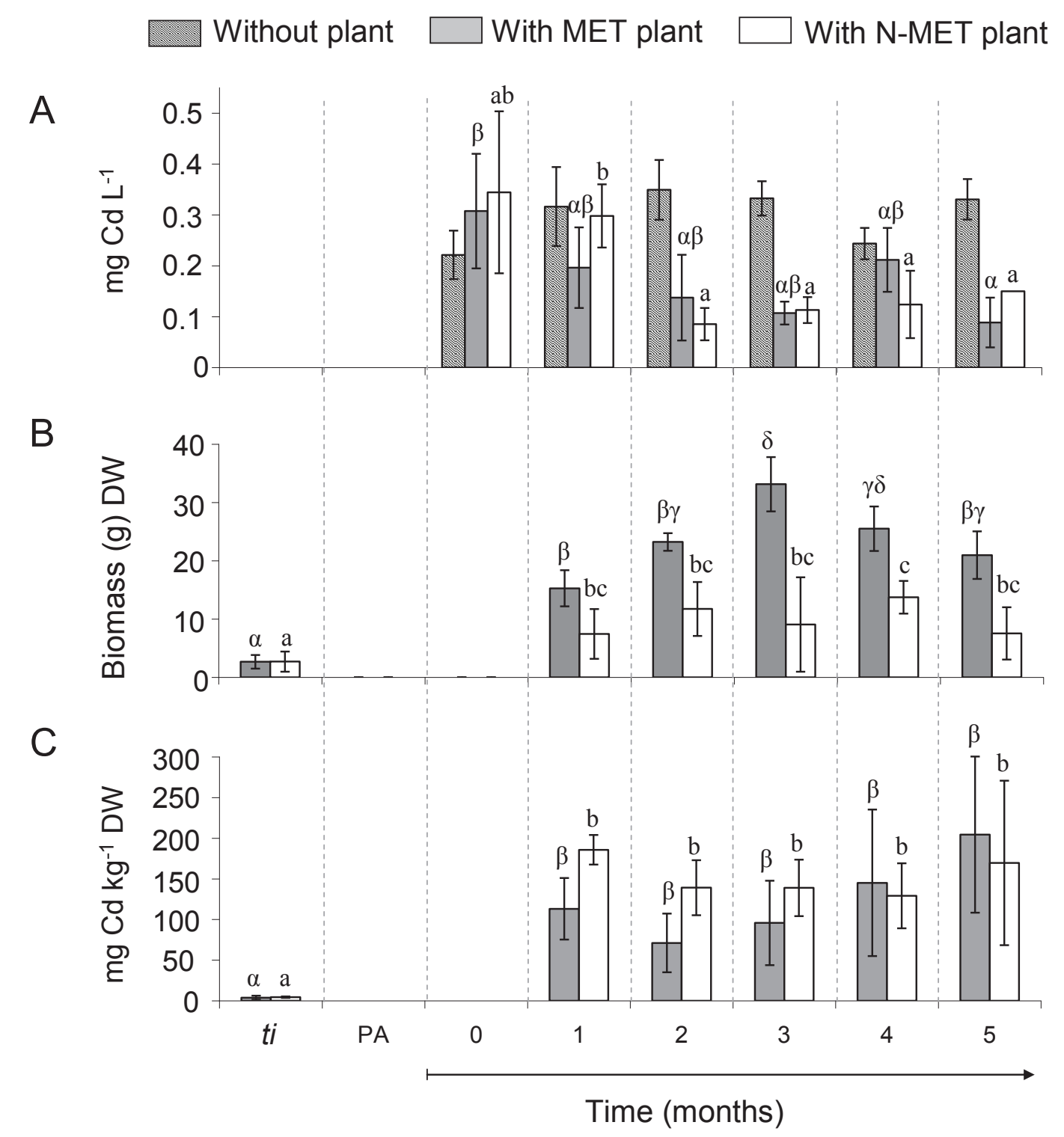

Figure 11. 


\section{Supporting informations_Science of Total Environment}

\section{Article : "Fate of cadmium in the rhizosphere of Arabidopsis halleri grown in a contaminated dredged sediment".}

Huguet Stéphanie, Isaure Marie-Pierre, Bert Valérie, Laboudigue Agnès, Proux Olivier, Flank Anne-Marie, Vantelon Delphine and Sarret Géraldine

\begin{tabular}{|c|c|c|c|c|}
\hline \multirow{4}{*}{$\begin{array}{ll}\text { Clay } & <2 \mu \mathrm{m} \\
\text { Silt } & 2 \mu \mathrm{m}-50 \mu \mathrm{m} \\
\text { Sand } & 50 \mu \mathrm{m}-2 \mathrm{~mm}\end{array}$} & \multirow{4}{*}{$\begin{array}{l}\% \\
\% \\
\%\end{array}$} & \multicolumn{2}{|c|}{ Hautes Fagnes soil } & \multirow{2}{*}{$\begin{array}{c}\begin{array}{c}\text { Auby soil } \\
\text { (Sarret et al., 2004) }\end{array} \\
(54)^{*}\end{array}$} \\
\hline & & 19 & (1) & \\
\hline & & 64 & (1) & \\
\hline & & 17 & (1) & 46 \\
\hline $\mathrm{CaCO}_{3}$ (total) & $\%$ & 0.3 & (1) & \\
\hline TOC & $\%$ & $9.16 \pm 0.9$ & (3) & \\
\hline $\mathrm{pH}, \mathrm{H}_{2} \mathrm{O}$ & & $6.94 \pm 0.05$ & (3) & 6.2 \\
\hline OM & $\mathrm{g} \mathrm{kg}^{-1}$ & 278 & (1) & 403 \\
\hline CEC Metson & $\mathrm{cmol}(+) \mathrm{kg}^{-1}$ & 29.5 & (1) & $52.7 \pm 1.6^{*}$ \\
\hline $\mathrm{K}\left(\mathrm{K}_{2} \mathrm{O}\right)$ exchangeable & $\mathrm{g} \mathrm{kg}^{-1}$ & 0.18 & (1) & $0.985 \pm 0.004^{*}$ \\
\hline $\mathrm{Mg}(\mathrm{MgO})$ exchangeable & $\mathrm{g} \mathrm{kg}^{-1}$ & 0.15 & (1) & $1.123 \pm 0.011^{*}$ \\
\hline $\mathrm{Ca}(\mathrm{CaO})$ exchangeable & $\mathrm{g} \mathrm{kg}^{-1}$ & 3.23 & (1) & $13.06 \pm 0.03^{*}$ \\
\hline $\mathrm{Na}\left(\mathrm{Na}_{2} \mathrm{O}\right)$ exchangeable & $\mathrm{g} \mathrm{kg}^{-1}$ & 1.86 & (1) & $0.0352 \pm 0.0003^{*}$ \\
\hline $\mathrm{P}\left(\mathrm{P}_{2} \mathrm{O}_{5}\right)$ Olsen & $\mathrm{g} \mathrm{kg}^{-1}$ & 0.04 & (1) & 2.0 \\
\hline Cd concentration & $\mathrm{mg} \mathrm{kg}^{-1}$ & $0.90 \pm 0.21$ & (15) & 270 \\
\hline Zn concentration & $\mathrm{mg} \mathrm{kg}^{-1}$ & $88 \pm 20$ & (15) & 21078 \\
\hline Cu concentration & $\mathrm{mg} \mathrm{kg}^{-1}$ & $24.8 \pm 4.3$ & (15) & 406 \\
\hline $\mathrm{Pb}$ concentration & $\mathrm{mg} \mathrm{kg}^{-1}$ & $109 \pm 15$ & (15) & 9135 \\
\hline Ni concentration & $\mathrm{mg} \mathrm{kg}^{-1}$ & $18.5 \pm 2.9$ & (15) & \\
\hline As concentration & $\mathrm{mg} \mathrm{kg}^{-1}$ & $17.7 \pm 2.8$ & (15) & \\
\hline
\end{tabular}

* Value including clays and silts

Figure SI-1: General properties of two different soils where $A$. halleri seeds were collected : Grain size distribution, sediment carbonate content $\left(\mathrm{CaCO}_{3}\right)$, Organic total carbonate (TOC), $\mathrm{pH}$, organic matter content (OM), cation exchange capacity (CEC), exchangeable cations and heavy metal concentrations. Averages and standard deviations over (n) samples. 

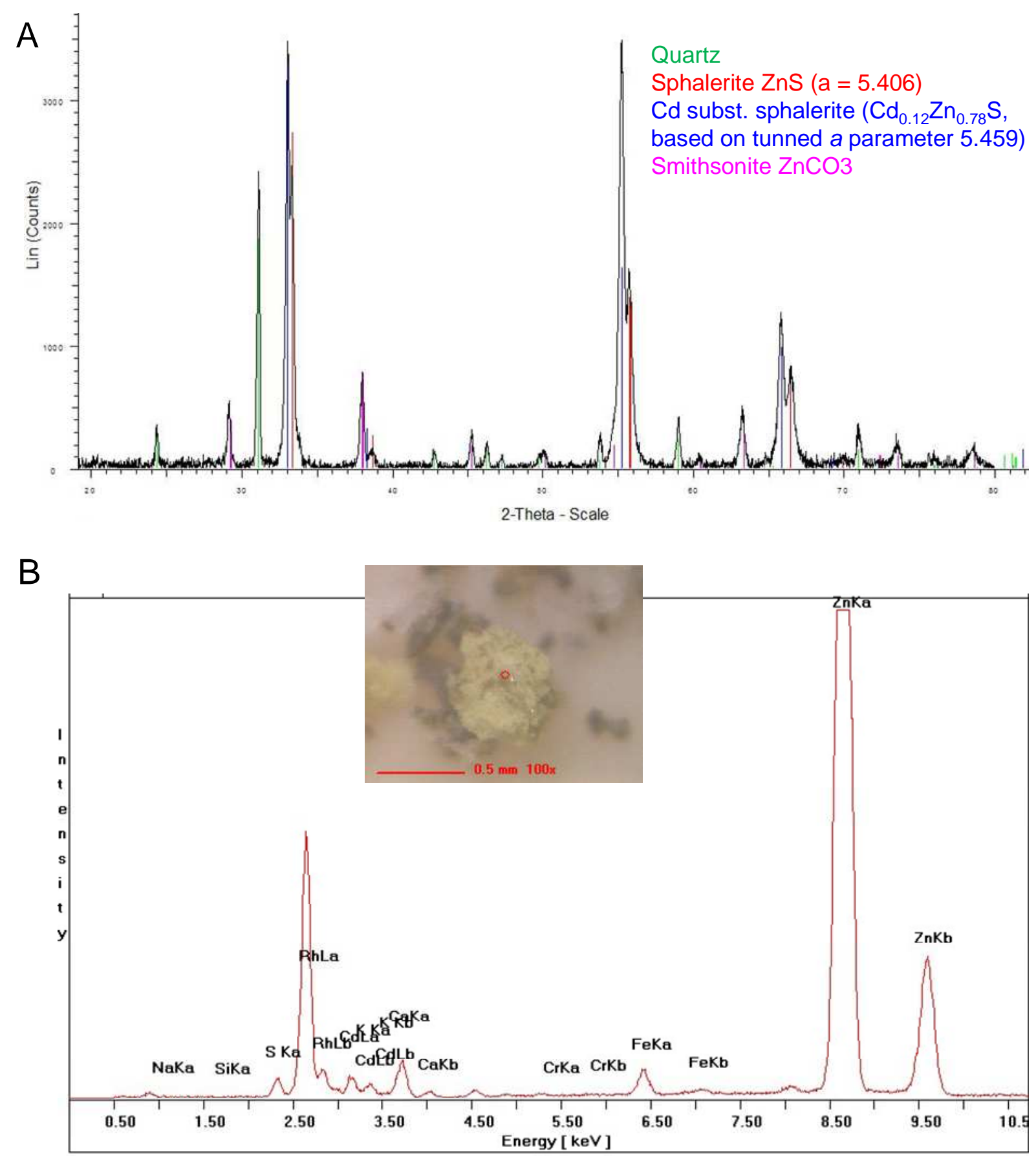

Figure SI-2: Characterization of the natural mixed sulfide reference: A: X-ray diffractogram. B: $\mu$ XRF spectrum (incident beam: $40 \mathrm{kV}, 200 \mu \mathrm{A}$ ) 


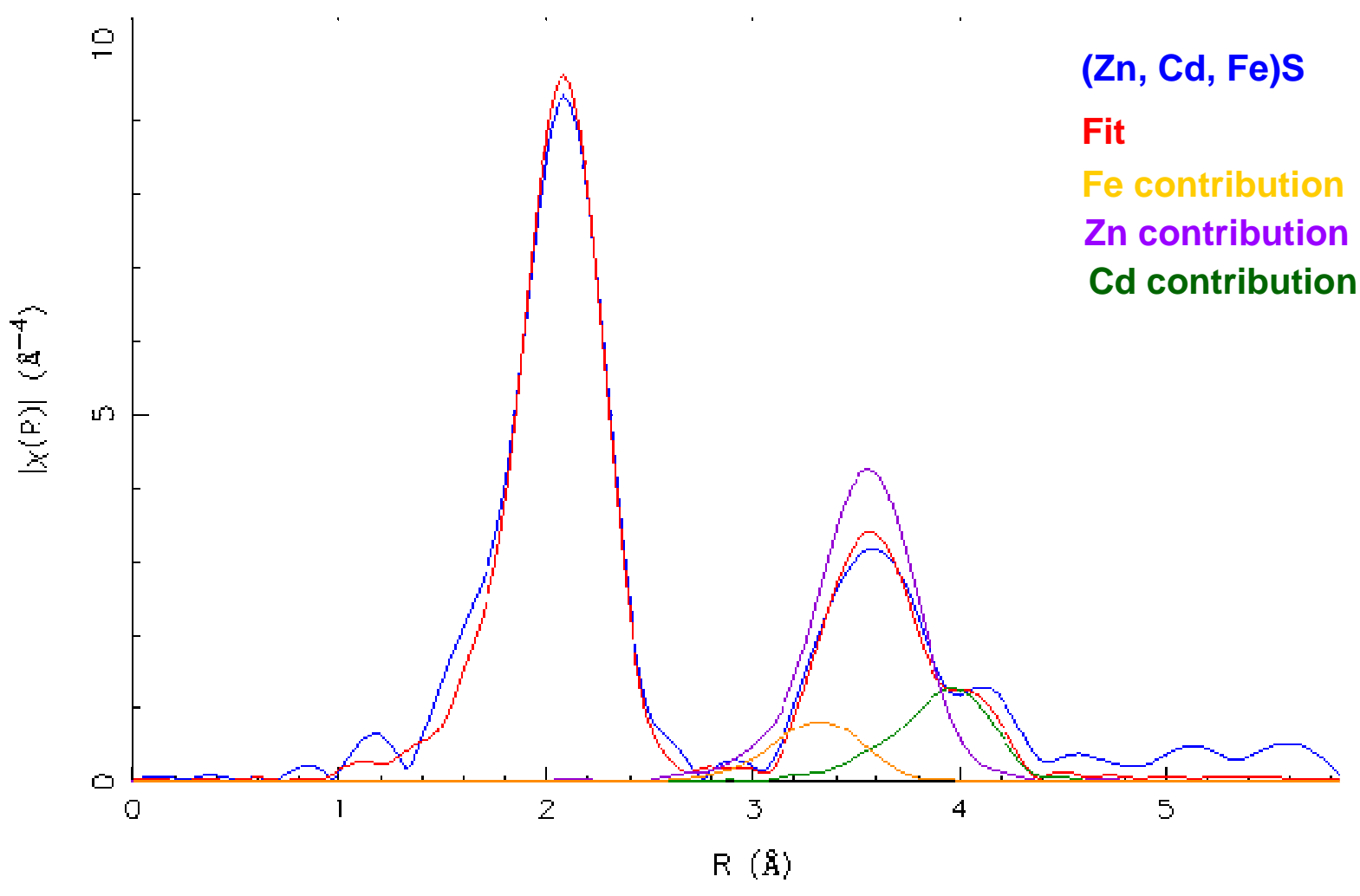

Figure SI-3: Fourier transform modulus of the $k^{3}$.chi $(k)$ spectrum for the mixed sulfide ( $Z n$, $\mathrm{Cd}$, Fe)S reference compound (blue) and shell fitting (red). Fe, $\mathrm{Zn}$ and $\mathrm{Cd}$ individual contributions for the second shell are shown. 